\title{
The Influence of the School of Salamanca in Alonso de la Vera Cruz's De dominio infidelium et iusto bello
}

\author{
First relectio in America
}

Virginia Aspe

What was the reach of the School of Salamanca in 16th-century America? This chapter focuses on a relectio of Alonso de la Vera Cruz, De dominio infidelium et iusto bello, which, as the first relectio to have been written in America, exemplifies the influence of some key writings of the School of Salamanca in 16thcentury America. Vera Cruz's "American" reappraisal of Francisco de Vitoria's famous writings, especially his Relectio de Indis, indicates that Salmantine ideas were not uncritically received. On the contrary, a detailed comparison of both relectiones reveals that the ramifications of the differences between both approaches to the polemical asuntos de Indias are further reaching than has been understood by current scholarship, for an indirect but clear criticism of some of Vitoria's positions can be discerned in the works of his student Vera Cruz. This chapter re-evaluates Vera Cruz's disagreement by examining, in particular, whether it responded to a foundational discourse in the Americas or was already embedded in it and only progressively distanced itself from earlier approaches elaborated by the first generation of Peninsular Salamanca masters, such as Vitoria and Soto.

In recent decades, Alonso de la Vera Cruz has emerged as one of the most important "American" masters of the School of Salamanca. His writings, in particular his treatise De dominio infidelium et iusto bello, ${ }^{1}$ have attracted increasing interest, ${ }^{2}$ not least since the publication of a wide - but incomplete - selection

1 In this chapter, I will quote Burrus's English translation of Vera Cruz's De dominio infidelium within the body of the text, Vera Cruz, The Writings of Alonso de la Vera Cruz, vol. II, 1. The quotations in Latin of Vera Cruz's relectio which appear in the footnotes are taken from the version of the text provided by Roberto Heredia Correa, who translated De dominio infidelium into Spanish in 2007 .

2 Some recent publications include Méndez Alonzo, "La teoría tomista del poder político de Alonso de la Veracruz"; Quijano Velasco, Las repúblicas de la Monarquía; Quijano Velasco, "Alonso de la Veracruz"; and Heredia Correa, "Coacción para la fe". 
of his works by Ernest Burrus (1968-1976). ${ }^{3}$ While my previous writings on Vera Cruz have focused mainly on his juridical and political thought, ${ }^{4}$ this chapter sets out to make a detailed comparison of Vera Cruz's De dominio infidelium with Vitoria's well-known Relectio de Indis. It will then, having made the comparison with the works of Vera Cruz that were written in New Spain, integrate this analysis into a general reflection on the kind of influence that Vitoria and Salamanca exerted over their students. ${ }^{5}$ Vera Cruz presented his first relectio at the recently instituted University of Mexico in $1554,{ }^{6}$ more than 20 years after concluding his studies at the University of Salamanca's faculty of theology (1528-1532), ${ }^{7}$ where Vitoria was the leading figure and held the prima chair of theology from $1526 .^{8}$ Despite the lack of documentary evidence, it is possible to assume that they remained in contact after Vera Cruz's departure for New Spain in $1536 .{ }^{9}$ Through an intermediary, Vera Cruz became acquainted

3 In five volumes of Latin and Spanish writings translated into English by Burrus from 1968 to 1976, Vera Cruz, The writings of Alonso de la Vera Cruz.

4 See Aspe Armella, "Integración cultural y ley natural en el Speculum coniugiorum de Alonso de la Veracruz", "Análisis del placer y la sexualidad matrimonial en Alonso de la Veracruz", and "Del viejo al nuevo mundo: el tránsito de la noción de dominio y derecho natural de Francisco de Vitoria a Alonso de la Veracruz".

5 I also dedicated a book to this topic in 2014, Aspe Armella and Zorroza, Francisco de Vitoria en la Escuela de Salamanca y su proyección en Nueva España, but I was only able to generally trace the reception of Aristotle and Aquinas in the writings of Alonso de la Vera Cruz in my brief contribution. See Aspe Armella, "El aristotelismo de la primera etapa de la Escuela de Salamanca".

6 For the most detailed research into the teaching activities of Vera Cruz in the recently created University of Mexico, see Pavón, "La Universidad de México en tiempos de fray Alonso de la Veracruz".

7 Alonso de la Vera Cruz, né Alonso Gutiérrez, was born in Caspueñas in the diocese of Toledo in 1507 and died in Mexico in 1584. He came from a well-off family who financed his studies in rhetoric and Latin at the University of Alcalá, and his education in arts and theology at the University of Salamanca (1528-1532). He worked as preceptor of the sons of the Duque del Infantado (1532-1535), when the Augustinian friar Francisco de la Cruz, who had temporarily returned to Spain in search of young missionaries, convinced him to sail to America. A recent detailed biography of Vera Cruz can be found in Lazcano, Fray Alonso de Veracruz (1507-1584), misionero del saber y protector de indios.

8 A full list of the courses that Alonso de la Vera Cruz attended or could have attended at the University of Salamanca in the period $1528-1532$ can be found in Ramírez González, "Alonso de la Veracruz en la Universidad de Salamanca", 635-652.

9 Once the young Alonso Gutiérrez arrived at the Port of Veracruz, he changed his family name to that of the city and entered the Augustinian order. After a year as a novice in Mexico City, Vera Cruz was sent to work as a missionary in Michoacán where, given his previous studies at Alcalá and Salamanca, he was immediately appointed as master of arts in different colleges founded by the Augustinian order in that wide region of central Mexico. In these colleges, he established the first American libraries and became well known for his 
with Vitoria's relectiones, De Indis and De iure belli. These relectiones had been delivered at the University of Salamanca in 1539 in an attempt to influence the principles guiding the Spanish colonisation of the Western Indies, ${ }^{10}$ which had hitherto proved to be erratic, fruitless, and cruel. 15 years later, Vera Cruz paid homage to Vitoria, even as he sought to correct some of Vitoria's arguments through the empirical data he had gathered from his experiences in New Spain. ${ }^{11}$ As he opened his brief but interesting career as a university professor in Mexico City with a relectio, ${ }^{12}$ Vera Cruz again took up the same issues his teacher had addressed in his American relectiones: the legitimacy of the

detailed knowledge of native customs. He learned Purépecha and other indigenous languages and began to record, little by little, many indigenous practices and rituals, underlining the peculiar rationality reflected in these traditions. The experience Vera Cruz gained from 1537 onwards can be seen in the writings he published almost 20 years later. He began to acquire a very good reputation as one of the wisest men in New Spain and was named provincial of the Augustinian order of Mexico for the first time in 1548 (an office that he held on several occasions throughout his life). Unlike other friars, he maintained a good relationship with the secular clergy during these first years in Michoacán, particularly with the bishop of Michoacán, the jurist Vasco de Quiroga, and replaced him as governor of the diocese for a few months in 1542. As Carrillo Cazares has shown, this idyllic relationship devolved into a fierce hostility from the 155 os onwards, when the rapid expansion of the Augustinian order threatened the hegemony and revenues of the secular Church. Carrillo Cazares, Vasco de Quiroga [...]: el pleito con la Orden de San Agustín 1558-1562.

10 See Belda Plans, Estudio crítico. Francisco de Vitoria, 32.

11 Vera Cruz often underlined this direct experience in his writings, calling himself an eyewitness ("testis sum oculatis") as evidence for some of his most polemical and critical statements, Vera Cruz, De dominio infidelium, 108.

12 In 1553, when the royal letters of foundation of the university arrived in Mexico City, Vera Cruz was appointed professor of Holy Scripture. Taking into account his formal education and his long teaching experience, he obtained his master's and doctoral degree in theology without being examined. Vera Cruz only held the chair of Holy Scripture for a few weeks. Considered by the Augustinians as less important than the prima chair of theology, which had been granted to the Dominican Pedro de la Peña, the Holy Scripture chair was quickly transformed into a chair of Saint Thomas and declared to be equivalent to the prima chair. See Pavón, "La Universidad de México en tiempos de fray Alonso de la Veracruz". Vera Cruz also wrote prolifically from 1554 to 1557. Apart from at least two polemical and therefore unprinted relectiones (De dominio infidelium et iusto bello 1554-

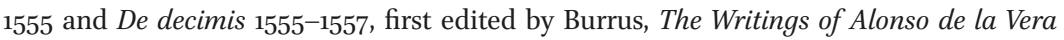
Cruz, vol. IV, and recently translated into Spanish by Luciano Barp, Sobre los diezmos), he managed to conclude and publish an entire course for the faculty of arts in Mexico City, which he probably started to write during the long period he taught at the faculty of arts and Augustinian colleges of Michoacán. The books Recognitio summularum cum texto Aristotelis (1554), Dialectica resolutio cum texto Aristotelis (1554), and Phisica speculatio (1557) formed the three parts of Vera Cruz's course on the arts. Another key publication for the history of "American" theology and canon law is his Speculum coniugiorum, first printed in Mexico City in 1556 . 
dominion of indigenous peoples, the just and unjust titles of the Spanish conquest, the claims of universal dominion by the pope and the emperor, etc. His critique of De Indis and other Salmantine writings contributed to an evaluation of the School of Salamanca that could be considered as a case of global knowledge production. ${ }^{13}$ It highlighted the points of agreement and difference between the first generation of Salamanca scholars (Vitoria, Soto, Azpilcueta, et al.) and their students, for, using objective criteria, it also critically evaluated the School's influence and impact on writings produced in America. As Duve highlights in the opening chapter of this book, some of the School of Salamanca's methods were followed in other European and colonial American universities, but instead of copying methodologies and content, we can say that Salamanca's arguments were adapted according to the specific needs of these diverse contexts. The case of Vera Cruz serves to illustrate another one of Duve's methodological remarks: that the communication between Salamanca and America was not unidirectional. In fact, knowledge and experiences circulated in both directions across the Atlantic, incentivising the production of a scientific and normative knowledge that resulted from the activities of many dispersed actors. It should therefore be stressed that the School of Salamanca was not a static school imposing premises and arguments on theological or juridical matters from a centre to a passive periphery.

As has been established, the methods of teaching and argumentation developed by Vitoria, Soto, and Medina (among other chair holders at Salamanca's faculty of theology), the topics discussed at Salamanca and the history of Salamanca's debates on key polemical issues (the legitimacy of the conquest of the Western Indies, clandestine marriage, new commercial practices that were problematically close to hidden forms of usury, etc.) undoubtedly had a global impact on the kingdoms and provinces of the early-modern Spanish empire. This influence also reverberated in regions such as Peru, ${ }^{14}$ New Spain,,${ }^{15}$

13 See the introductory chapter by Thomas Duve in this book and some of his previous writings on this issue, e. g. "Salamanca in Amerika".

14 A region to which Walter Redmond dedicated most of his writings since his pioneering Bibliography of the Philosophy in the Iberian colonies of America. Recent studies have been dedicated to the scholastic juridical writings of key historical figures, such as Domingo de Santo Tomás (see Torre Rangel, "El memorial de Las Casas y fray Domingo de Santo Tomás") and Diego de Avendaño (see some of Cuena Boy's contributions, "La prohibición del matrimonio", "Teoría y práctica de la ley", "El castigo de las injurias causadas a los indios"), in a constant dialogue with the Salamanca masters.

15 See, for example, the classical writings of Mauricio Beuchot and Walter Redmond on early-modern Mexican scholasticism, closely linked to the Salamanca methods, topics, and approaches, La lógica mexicana del siglo de oro, Pensamiento y realidad en fray Alonso de la Vera Cruz, Historia de la filosofía en el México colonial. 
the Philippines, ${ }^{16}$ Portugal, ${ }^{17}$ Naples, ${ }^{18}$ and Central and Northern Europe. ${ }^{19}$ Many academics studying Salamanca's influence in America still assume that American scholastics merely regurgitated the approaches and doctrines taught by well-known Peninsular Salamanca masters (Vitoria, Soto, Cano, etc). ${ }^{20}$ This chapter raises and examines some of these unanswered questions through an analysis of the works of Vera Cruz. What specific orientations were closely associated with Salmantine jurists and missionary theologians in the Americas? What solutions did they find to resolve the unparalleled dilemmas they confronted in the field? What was the nature and extent of the influence of the School of Salamanca in the Americas? Were those American authors only passive recipients of ideas emerging from their alma mater? Did they manage to "localise" the general doctrines learned in Salamanca and go on to produce normative knowledge that responded to specific American customs and to the challenges posed by their own epochal and regional working contexts? This chapter addresses these broad themes by approaching them more concretely through using a representative text to study how Salamancan methods and teachings were culturally translated for the distant American regions: Vera Cruz's Relectio de dominio infidelium et iusto bello (1554-1555).

The choice of text might strike the reader as odd for this task because the quaestiones, structure and order of De dominio infidelium seem to have been influenced by Vitoria, particularly the manner in which he first addressed these topics in his monumental Relectio de Indis that later became commonplace in the debates over asuntos de Indias. However, despite the assumption

16 See the contributions of Cobo, Camacho, Folch, and Moutin in this volume and Cervera Jiménez, "The School of Salamanca at the end of the known world in the 16th century".

17 As is well known, Martín de Azpilcueta, Francisco Suárez, and Luis de Molina were key figures of the first and second generation of scholars of the School of Salamanca, who taught at the faculty of theology at the University of Coimbra and were once students and/or teachers at the Salamancan faculty of theology. There are different monographs studying the strong intellectual connections between Salamanca, Coimbra, and Évora in the 16th and 17th centuries: Pereña, "Francisco de Vitoria en Portugal", Marcos de Dios, Portugueses na Universidade de Salamanca (1550-1580) and "Portugueses en la Universidad de Salamanca". See also Lanza's and Toste's chapter in this book.

18 In Naples, moral theologians such as Antonino Diana and jurists such as Giacomo Antonio Marta worked in continuous dialogue with the writings of their Salamanca colleagues and themselves greatly influenced 17 th century Salamanca authors such as Solórzano. A vast panorama of the intersections of these longstanding European influences are detailed in Quantin, "Catholic Moral Theology, 1550-1800".

19 As found in the writings of authors such as Lessius, Grotius, and Pufendorf, among many other key figures of modern juridical and theological thought. See Enrique González's critical perspective on the traditional historiography in this book. 
that Vera Cruz had written his own relectio with De Indis in mind - of which Vera Cruz might have acquired a manuscript copy before 1554 - Vitoria was not quoted once in De dominio infidelium et iusto bello.

The following pages detail the salient features of Vera Cruz's writings in order to challenge the assumption that his relectio was merely a transplant or an acritical adaptation of Vitoria's De Indis for the Mexican context. ${ }^{21}$ His writings drew not only on the works of Salamanca scholars but also on the experiences he himself had gained over a period of almost 20 years in New Spain, where he wrote his De dominio infidelium. A detailed comparison of De Indis and De dominio infidelium in the last sections of my contribution will serve to prove this hypothesis. Before analysing these texts however, it is necessary to first examine the authors and trends in philosophical, theological, and jurid-

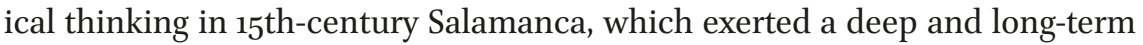
influence on 16th-century scholastics like Vera Cruz.

\section{Beyond Vitoria: "El Tostado" (1410-1455), Martínez Silíceo (1477- 1557), and Other Salamanca Masters behind the Writings of Alonso de la Vera Cruz}

Many experts of the history of the University of Salamanca during the Middle Ages consider Alonso Fernández de Madrigal, "El Tostado" (1410-1455), a key figure in Spanish intellectual history for founding the kind of practical and proto-rationalist theology that distinguished Salamanca scholasticism in the early modern period. Delgado Jara has proved how his biblical exegesis

21 Another differentiating element highlighted by experts of the legal history of colonial Mexico, such as Carrillo Cazares, who nevertheless did not engage in a detailed comparison between the relectiones of Vitoria and Vera Cruz. Carrillo Cazares focused on the way that the contemporary war the Spanish settlers fought against the Chichimeca Confederation in Central and Northern Mexico influenced Vera Cruz's thoughts on war, "Aunque son de enorme interés en la explicación del paralelismo entre el examen que Vitoria hace de los títulos legítimos e ilegítimos de la guerra justa y la disertación que fray Alonso escribe sobre las mismas causas justificantes e injustificantes, no es este el punto que por ahora nos interesa, sino ante todo exponer el pensamiento veracruciano sobre la justificación teórica de la guerra. Como discípulo de Vitoria, fray Alonso sigue el modelo doctrinal de su maestro, pero con la ventaja que ha obtenido de su experiencia indiana que le faculta para aplicar la mayor parte de su exposición a los hechos históricos y a las condiciones que prevalecían realmente en las diversas provincias del orbe indiano. De esta manera su tratado va más allá de las provisorias hipótesis planteadas por el maestro de la Escuela de Salamanca", Carrillo Cazares, El debate sobre la guerra chichimeca, Vol. $I, 149$. 
of many books of the Old Testament and the Gospel of Saint Matthew, which remained unfinished, ${ }^{22}$ went beyond Thomas Aquinas's doctrine about the proper way to interpret Holy Scripture (STh, Prima Pars, q. 1, arts. 9-10) and the exegetical methods adopted by 14th-century authors like Nicolas de Lyre. El Tostado "argumenta menos con autoridades que con razones". He also contrasted previous scriptural commentaries with a repertoire of theological, philosophical, and juridical authorities not seen hitherto. Putting aside sterile and futile disputes on speculative subtleties and the logical and rhetorical interests of early scholastics, El Tostado focused on "la problemática y las preocupaciones de su tiempo (la Guerra, el derecho de gentes, las ideas políticas, la renovación moral, $[\ldots])$ ".. ${ }^{23} \mathrm{He}$ was, in this sense, a forerunner of the 16th-century practical theology found in Vitoria, Soto, and Vera Cruz, as well as many other Iberian scholastics.

By the mid-15th century, El Tostado was an active and decisive member of the corporation of the University of Salamanca in theoretical and practical matters, ${ }^{24}$ as well as the key "intellectual" who introduced new approaches to Aristotelianism in the faculties of arts and theology, which diverged significantly from the previous Arabic reading methods such as that of Averroes. El Tostado had held the chairs of moral philosophy and rhetoric from the late 143 os in the faculty of arts, and he was also appointed chair of the Holy Scripture in the 1440s, and later of vespers in the faculty of theology. ${ }^{25} \mathrm{He}$ went on to reform the arts and theology curricula, extending the authority of Aristotle to an important part of the disciplines then studied at the university. ${ }^{26}$

El Tostado, who had studied arts and theology and held a bachelor's degree in law, exemplifies the increasing importance of theologians and of a multinormative perspective on social regulation in the Castilian royal administration. Promoted simultaneously to the offices of chancellor (canciller del sello, 1444), judge (oidor) of the Real Audiencia, and member of the Royal Council (1553) Kings, 1-2 Chronicles, see Delgado Jara, "El Tostado y la exégesis bíblica", 57.

23 Delgado Jara, "La hermeneútica bíblica en el siglo XV", 454-455.

24 Apart from his different teaching commitments, El Tostado was maestrescuela of the University between 1446 and 1454, when he became ill and died. He was responsible for the construction of the walls surrounding the Escuelas Mayores of the university and a vast plan to reconstruct and enlarge the classrooms. See Rodríguez-San Pedro Bezares, "La Universidad de Salamanca: de los reyes a los pontífices, 1255-1450", 215.

25 Contemporary literature on this period of the history of the University of Salamanca, obscured by archival lacunae, still seems to rely on classical studies such as that of Beltrán de Heredia, "El profesorado salmantino durante la primera mitad del s. XV", 166. Castillo Vegas, "Aristotelismo político en la Universidad de Salamanca del siglo XV", 39. 
during the last years of the reign of Juan $\mathrm{II}^{27}$ he introduced normative theological and moral-philosophical criteria to processes devoted to navigating the fraught relationship of the kings with the nobility, the difficult convivencia of Jews, Muslims, and Christians in contemporary multicultural Castile, and the recurring frictions between pontifical and royal jurisdictions. The case of El Tostado - similar to those of other contemporary theologian-counsellors such as Lope de Barrientos, a Dominican friar who held the prima chair of theology at Salamanca together with the most important juridical offices during the reigns of Juan II and Enrique IV and different bishoprics ${ }^{28}$ - thus represented an important milestone in a prolific dynamic of normative knowledge production which had started with the creation of the faculty of theology at the University of Salamanca in $1411,{ }^{29}$ until then clearly focused on juridical studies. This led to the continuous requests for counsel and opinions that we find during the era of Charles $\mathrm{V}$ and Vitoria, when Vitoria and other Salamanca theologians intervened in delicate matters such as the wars of conquest and the evangelisation of the Americas, the divorce of Henry viII and Catherine of Aragon, and the writings of Erasmus.

Recent studies on Alonso Fernández de Madrigal's political and juridical thought have pointed to a diffusion of theological and moral normativity into the courtly atmosphere as much as to a progressive incorporation of courtly debates (interaction between different social estates, moral evaluation of the ambitions of many clergymen, the need and importance of advice and counsel, etc.) into scholastic reflection to explain these developments. This was articulated through the conceptual frameworks of Aquinas and the original works of Aristotle - whose most important writings were recovered during the course of the 15th century by Italian scholars, Leonardo Bruni being the most important one, in close dialogue with El Tostado, Alonso de Cartagena, and other Salamanca masters. ${ }^{30}$ These examined social life and its organisation

27 See Belloso Martín, Política y humanismo en el siglo XV, $26-28$.

28 See Cañas Gálvez, Burocracia y cancillería en la corte de Juan II de Castilla (1406-1454), 46.

29 Until this period, and since at least 1381, there were two theological chairs in the Dominican and Franciscan convents in Salamanca, see Pena González, "Proyecto salmantino de Universidad Pontificia e integración de la Teología en el siglo XV" and the recent approach of Monsalvo Antón, "Impulso institucional e intelectual del Estudio, c. 138o-c. 1480", 51-108.

30 On the intense debates between Cartagena and Bruni over the proper way of translating and interpreting Aristotle and the impact of this on El Tostado, see Morrás, "El debate entre Leonardo Bruni y Alonso de Cartagena"; Cartagena, Los libros de Tulio: De senetute, De los ofiçios; and Wittlin, "El oficio de traductor según Alfonso Tostado de Madrigal". 
through notions of concord and friendship in politics. ${ }^{31}$ Apart from the continuous evaluation of key political and juridical quaestiones in an innovative exercise of biblical exegesis articulated through utrum questions, Fernández de Madrigal wrote various political treatises in both Latin and vernacular Castilian, some of which have been preserved (De optima politia, ${ }^{32}$ Breviloquio de amor e amiciçia, Tratado de cómo es necesario al hombre amar). ${ }^{33}$

El Tostado's approach was not isolated and without consequence because his disciple, Pedro Martínez de Osma - prima chair of theology in later decades -, and his disciple's disciple, Fernando de Roa, continued privileging lectures on Aristotle's Politics and Ethics to explain the nature of the different forms of rule and government, the limits of any true royal dominion that stopped short of tyranny, the relationship between secular and ecclesiastical authorities, etc. ${ }^{34}$ Writing in the period when conciliarism had achieved important victories over papal aspirations of absolute control of the Church, El Tostado, Osma, and Roa agreed that the pope could not only be mistaken about faith and human matters, but also about accusations of heresy if, despite being persuaded of his errors by the council, he obstinately persisted in propagating his incorrect opinions. ${ }^{35}$ All those positions, the result of long and harsh debates between Salamanca theologians before the arrival of Vitoria, appeared frequently in the writings of Vera Cruz. For example, in his Speculum coniugiorum - where El Tostado was quoted numerous times, second only to Aquinas in terms of frequency,$-{ }^{36}$ the idea that the pope and pontifical canons (only in the argumentative part and not in the resolutive one, which always had to be obeyed) could be wrong and did not have to be obeyed when the authority of many doctors and biblical paragraphs could be alleged to defend a contrary or different position. ${ }^{37}$ Vera Cruz resorted to the authority of El Tostado's

31 See Sabido, Pensamiento ético-político de Alfonso de Madrigal, 25-40.

32 Fernández de Madrigal, De optima politia. El gobierno ideal.

33 El Tostado's writings on love and friendship as social and political virtues were edited together by Pedro Cátedra, Del Tostado sobre el amor.

34 José Labajos Alonso edited the commentaries to Aristotle's Politics and Ethics by Pedro de Osma and Fernando de Roa, along with other relectiones and academic writings of these two Salmantine masters.

35 "Et non solum accidit hoc circa accidentia, \& particularia, factaque humana, quae Papa ignorat, sicut quilibet alius simplex homo, sed etiam circa fidem potest Papa ignorare, \& errare, \& effici haereticus aliquando per ignorantiam, aliquando per aliam affectionem. Sic patet in Decret. Distinct. 40. Cap. Si Papa. Ubi si Papa deprehenditur a fide devi is deponitur", Fernández de Madrigal, Defensorium trium conclusionum, Cap. xxx, 45.

36 See Egío's chapter in this book.

37 "Sic contingere potest summum Pontificem aliquis asserendo falsum dicere, \& decipi, quia homo est: \& tunc velut homo cognitionem habens loquitur. At quia alii sunt, qui 
(Abulensis) Defensorium to uphold this particular position, which had obviously become very problematic in the new context of confessionalisation following the Reformation.

Another significant influence in Vera Cruz's life and thought was, without doubt, his teacher at Salamanca, Juan Martínez Silíceo. Contrary to the historiography on Vera Cruz, which, on the basis of unverified assumptions, has enthusiastically emphasised the filiation between the great Vitoria and his Augustinian disciple and exaggerated it to increase the prestige of both Vitoria and Vera Cruz, ${ }^{38}$ the archives at the University of Salamanca reveal a different reality. As Clara Inés Ramírez has proved in a noteworthy article - which aimed to challenge the depiction of Vera Cruz in traditional historiography as a kind, loyal, and uncritical replicator of Vitoria's legacy -, after concluding his bachelor's degree in theology (1528-1532), the Augustinian friar chose Juan Martínez Silíceo, the chair of natural philosophy and a great representative of nominalism in contemporary Spain, as the padrino who conferred his bachelor degree in theology on him..$^{39}$

Vera Cruz's free election of Martínez Silíceo as his padrino de grado reveals its full meaning when comparing the nominalist approach of Silíceo's writings on logic with those Vera Cruz published in Mexico some years later. ${ }^{40}$ Even the relatively free fluctuation between the three traditional theological viae (Thomist, nominalist, Scotist) that distinguished Vera Cruz's theological writings - a topic that will be addressed in the following section - could be related to the deep knowledge inherent in the different theological traditions that derived from Silíceo and other non-Thomist scholars. His election as padrino

licet non sint Pontifices, sunt plus a Deo illustrati, possunt melius inteligere veritatem, \& affirmare contrarium", Vera Cruz, Speculum coniugiorum, Secunda pars, Art. XXI, "An plus standum pontifices sententiae, quam doctorum", 373 .

38 An example of this perspective can be found in Prometeo Cerezo de Diego's work on Vera Cruz, "Particularmente interesante para el estudio del contenido de la doctrina de Veracruz es la influencia ejercida en él por sus maestros de Salamanca, especialmente por Vitoria. A juzgar por el testimonio mencionado de Grijalva, Veracruz debió de ser uno de los discípulos predilectos del 'Sócrates español', al que le cupo la suerte de realizar sus estudios teológicos poco después de posesionarse Vitoria de su cátedra de Prima y tal vez participar de aquellas tertulias domésticas que se organizaban en la celda del Maestro en el convento de San Esteban, motivadas por las visitas de sus alumnos más aventajados", Alonso de Veracruz (1507-1584) y el derecho de gentes, 23.

39 Ramírez González examined the ceremony in which Vera Cruz received his bachelor's degree, Archivo de la Universidad de Salamanca (AUSA), 566, fol. 56r. Ramírez González, "Alonso de la Veracruz en la Universidad de Salamanca", 646-647. 
de grado by Vera Cruz clearly implied the recognition of Martínez Silíceo as his intellectual mentor.

Martínez Silíceo held the chair of natural philosophy at the University of Salamanca from 1522. Despite his all-round talent in the disciplines of logic, natural philosophy, theology, canon law, and navigation, he is remembered above all for his decisive role in adopting the estatutos de limpieza de sangre when he became the archbishop of Toledo in $15466^{41}$ Given the prominent position of the archbishop of Toledo as primate of Spain, Silíceo's measure had a ripple effect on other institutions and led, in the mid-term, to the exclusion of converts from the Spanish church and royal offices, among other things.

Silíceo's formation closely resembled the one received almost contemporaneously by Vitoria. He had studied arts and theology at the University of Paris (Collège de Beauvais) in the 1510 s and arrived at the University of Salamanca as a renowned scholastic author. He took over as the teacher of nominal logics at Salamanca during the academic year of $1518-1519 .{ }^{42}$ As a student of Jean Dullaert, one of the most important translators and interpreters of Aristotle's logical and philosophical writings in the early 16 th century, Silíceo played an important role in the deep restructuring of Salamanca's arts faculty in the $1520{ }^{43}$ It has become clear that, driven by a strong commitment to emulating the innovative Paris curricula and keeping abreast of the methodological reform in the arts at different European universities, the university senate (claustro) commissioned two members to travel to Paris in 1516 to convince Silíceo to return to Spain and lead the efforts to restructure the arts faculty at Salamanca. ${ }^{44}$ An important part of Silíceo's mission was to write and print the new manuals on Logic for the arts students. It is known that Silíceo invested his time well and soon after his arrival at Salamanca, he managed to publish Dullaert's commentaries on the logical writings of Aristotle with the local Salmantine printers. Silíceo added his own remarks to the extant teaching materials in order to adapt them to the specific cultural and philosophical background of the students of Salamanca. ${ }^{45}$

41 Quero, Juan Martínez Silíceo (1486?-1557) et la spiritualité de l'Espagne pré-tridentine; Amrán, "De Pedro Sarmiento a Martínez Silíceo".

42 Flórez Miguel, "El ambiente cultural de Salamanca en torno a 'Silíceo' ", 132-142.

43 Flórez Miguel, “Presentación”, 11; Carabias Torres, Salamanca y la medida del tiempo, 68.

44 Espona, "El cardenal Silíceo", 44.

45 Dullaert, Martínez Silíceo, Questiones super duos libros Peri hermeneias Aristotelis una cum textu eiusdemque clarissima expositione doctissimi magistri Johannis Dullaert de Gandano adiecta Sylicei eiusdem Dullaert discipuli cura et vigilantia, Salamanca, Juan de Porras, 1517. Martínez Silíceo, Siliceus in eius primam Alfonseam sectionem in qua primaria dyalectices elementa comperiuntur argutissime disputata, Salamanca, [Juan de Porras?], 
It is no surprise that four decades later, when the chairs of the arts faculty at the recently founded University of Mexico were established (1554-1555), his student Vera Cruz engaged in a similar operation. Benefitting from various extant materials and inspired by the nominalist perspectives of Martínez Silíceo, Vera Cruz managed to publish the first books on logics and physics in Mexico that were - so to speak - "made in America": Recognitio summularum (1554), Dialectica resolutio (1554), and Physica speculatio (1557). Following his padrino's example, his writings on logic were published "cum textu Aristotelis" [with the text of Aristotle] and were humbly conceived of as an easy and quick method to assimilate the complex logical thinking of the Greek philosopher. Given that Mexican students were trained to undertake missionary tasks above all, ${ }^{46}$ Vera Cruz believed that many of Aristotle's abstract speculations which had no practical ends could be omitted or summarised.

A hypothesis that still needs to be evaluated is whether Silíceo's mistrust and intransigence towards the converso minority, who he believed should always be closely monitored by Old Christians, influenced Vera Cruz. As the detailed analysis of De dominio infidelium below demonstrates, Vera Cruz continued to argue that the conversion of indigenous peoples to Christianity (voluntary or forced) and keeping them in the "true faith" were the strongest and most genuine arguments that Spaniards could invoke to justify their actions in the Western Indies. A close reading of De dominio infidelium et iusto bello shows the influence of different, pre-Vitorian authorities who were part of this intellectual movement that was vaguely referred to as the Primera Escuela de

1517. Martínez Silíceo, Logica brevis Magistri Silicei cunctis, theologis, legumperitis, medicis, philosophis, rethoribus, grammaticus et omni literatorum sorti acommodata, Salamanca, [Juan de Porras?], 1521.

46 Vera Cruz himself made this very clear in the dedicatory epistles to his writings on logic. For example, presenting his Dialectica resolutio to the university senate, he considered logical knowledge as a kind of preliminary step for the debates about the true knowledge (that is to say, theology) in which the students would take part after the conclusion of their studies at the university. "Cum saepe mecum praemeditarer rector magnifice, doctores clarissimi, magistrique gravissimi, cui resolutionem dialecticam, quam in utilitatem eorum quibus brevi ad veram sapientiam, \& scientiarum reginam Theologiam pervenire in animo est, dicarem sponte sese obtulit vestrum hoc auspicatissimum Colegium, \& Schola: ex vobis veluti ex vivis quadratisque lapidibus nuper erecta [...] Quampropter doctores ornatissimi, hanc nostram opellam in Aristotelica dialectica, quam olim inter legendum absolvimus, vobis libentissime offerimus. Habeat posthanc vestrum hoc bonorum literarum uberrimum gymnasium, felicissimis auspitiis inchoatum, librorum suppellectilem: ut adolescentorum pullulantia ingenia, se se possint exercere: \& velut in agone contendendo, citissime ad illam maturissimam Theologiae frugem pervenire", Vera Cruz, Dialectica resolutio, [s.p.]. 
Salamanca. Links to the nominalist and Scotist schools of thought repeatedly appeared in Vera Cruz's writings, entering into dialogue - and sometimes conflict - with positions that could be attributed to Vitoria, Soto, Covarrubias, and other 16th-century Salamanca scholars. Contrary to what is usually said and written about Vitoria's students, Vera Cruz privileged more ancient authorities in most cases, choosing to cite El Tostado over Vitoria. In all likelihood, Vera Cruz could have compared and contrasted their positions using a manuscript version of De Indis he had at his disposal.

The study of the short- and long-term influences and the shared ideas between different late-medieval and early-modern Salamanca masters is crucial for understanding and redefining the School of Salamanca, given not only the confusion surrounding the term and the problematic identification of many jurists and theologians as members of the School, but also the distinction between different generations of authors within that general discursive community. Juan Belda Plans represents a strand of traditional historiography that leaves out any mention of medieval influences and renders Vitoria the starting point of the School of Salamanca. He distinguished between a first generation of masters that included theologians who were active between the decades of 1520 and 1560 (Vitoria, Domingo de Soto, Melchor Cano), and a second generation represented by figures like Bartolomé de Medina, Juan de Guevara, Mancio de Corpus Christi, Pedro de Herrera, Juan Márquez, and others who were active between the mid-156os and the beginning of the 17 th century. Based on that distinction, Belda defined the School of Salamanca as:

[...] un movimiento estrictamente teológico del siglo XVI, que se propone como objetivo primordial la renovación y modernización de la Teología, integrado por un grupo amplio de tres generaciones de teólogos, catedráticos y profesores de la Facultad de Teología de Salamanca, todos los cuales consideran a Francisco de Vitoria como el artífice principal del movimiento y siguen los cauces de renovación teológica abiertos por él, hasta principios del siglo XVII. ${ }^{47}$

This definition is problematic because it ignores the juridical, economic, and philosophical interests of many chair holders at the faculties of theology, law, and arts and restricts the lens through which contributions of the School of Salamanca are analysed. It also seems to conceive of Vitoria's work at Salamanca as emerging on a blank slate using a totally new language. This 
narrow, traditional definition gives rise to confusion because it excludes the important achievements of the so-called Primera Escuela de Salamanca, Martínez Silíceo and other central figures who were involved in the intense debates between nominalist and Thomist masters at the university long before the arrival of Vitoria.

As has been mentioned, the $15^{\text {th }}$ and the early 16 th centuries were extremely rich and momentous for the history of the University of Salamanca. Ideological controversies and disputes about the value of different philosophical and theological authorities (Aristotle, Aquinas, Scotus, etc.) had practical effects and led to important reforms in the curricula. In light of this, various experts have recently retraced the first steps of the dynamics initiated in 15th century Salamanca, from the full integration of the rediscovered and newly translated texts of Aristotle into many of the disciplines studied at Salamanca to the increased interest in the writings of Thomas Aquinas. Both elements are clearly noticeable in the works of El Tostado, Osma, Roa, and other Salamanca masters who all paved the way for the later systematic commentaries on the Summa theologiae, such as that undertaken by Vitoria in the $1520{ }^{4}{ }^{48}$

The juridical, political, and philosophical reflections of those pre-Columbian Salamanca masters are a key element in the revision of an extremely Vitoriacentred historiography on the School of Salamanca's projection and influence in America. As Egío underlines in the next chapter, where he also takes El Tostado's influence on Vera Cruz into account, the integration of the Primera Escuela de Salamanca in this historiography is an essential project that must be undertaken by future researchers because:

(1) It would allow us to move beyond the traditional theological focus and to study the cultural translation of a rich patrimony of knowledge that emerged from the Salmantine faculties of law and the arts. When considering such a brilliant Salamancan figure in America as Vera Cruz - who wrote theological treatises such as Speculum coniugiorum, juridical-political relectiones such as De dominio infidelium and De decimis, and an entire Cursus in the arts for the Augustinian colleges and the recently founded University of Mexico while also

48 See, among other important writings dedicated to this Primera Escuela, Sabido, Pensamiento ético-político de Alfonso de Madrigal, 21-40; Aspe Armella, "El aristotelismo de la primera etapa de la Universidad de Salamanca", 47-6o; Delgado Jara, "El Tostado y la exégesis bíblica", Villacañas Berlanga, "La ratio teológica-paulina de Alfonso de Cartagena", Rivera García, "Humanismo, representación y angeología”, and other contributions in Flórez Miguel, Hernández Marcos and Albares Albares, La Primera Escuela de Salamanca (1406-1516); Pena González and Rodríguez-San Pedro Bezares, La Universidad de Salamanca y el Pontificado en la Edad Media; and Pena González, De la Primera a la Segunda "Escuela de Salamanca". 
actively delving into other disciplines - it is impossible to get an adequate perspective of his contributions without taking into account the late medieval evolution of the Salamanca curricula, teaching methods, and approaches to raising and solving problematic practical cases.

(2) It would help us to better understand the debates over the authority of Aristotle that took place between different Salamanca masters and contemporary humanists such as Sepúlveda. This is a crucial point, given that those debates were highly relevant to the process of constructing the Salmantine argumentation on such topics as the infidels' dominion, slavery, conversion, and just war in the Americas. An important philosophical restructuring was underway in 15th century Salamanca when El Tostado, Osma, Roa, and other scholars entered into an intense debate about the political and ethical writings of Aristotle. This implies that when Vitoria, Sepúlveda, and Las Casas invoked Aristotle's authority to evaluate the political and juridical condition of the "barbaric" inhabitants of the Western Indies, they did not invent or establish something completely new, but rather were tilling an already fertile field within an established Castilian tradition.

(3) Innovations and re-evaluations in the hitherto unconnected fields of knowledge of theology, law, and the arts could finally be studied in tandem within the more ambitious and solid context of the history of knowledge production. For example, it has been proven that Leonardo Bruni's translations of Aristotle's writings were known and debated by Cartagena and El Tostado and officially used as teaching materials at Salamanca since Pedro de Osma's appointment as chair of moral philosophy in $1457 \cdot{ }^{49}$ This innovation led to a progressive abandonment of Boetius's translations of Aristotle. In the continuous process of revision undertaken by his students, Bruni's materials were supplemented with new Latin translations of humanists like John Argyropoulos, who was also working on the Florentine Aristotelian studium at that time. Argyropoulos's translations were also consulted by Juan Martínez Silíceo, Domingo de Soto, and Vera Cruz when writing their own works on logic and physics. $^{50}$

49 See Osma, Escritos académicos de Pedro de Osma, 111.

50 In his Dialectica resolutio, Vera Cruz used Argyropoulos's version of Aristotle's Analytica posteriora. Domingo de Soto, still using some of Boetius's texts, included Argyropoulos's translations of De interpretatione and Analytica priora. See Vega Reñón, "Alonso de Veracruz y las encrucijadas de la lógica en el siglo XVI", 120 and 122. In a previous investigation, I proved that, contrary to what might have been expected, Analytica posteriora was the most commented upon and quoted European text in the academic literature that was produced in early modern New Spain, rather than a political or theological text, see Aspe Armella, Aristóteles y Nueva España, 207-221. 
The Florentine translations and interpretation of Aristotle have been said to have represented a methodological revolution, initiating a period in which a newer and more authentic "Aristóteles humanista", different from "el de la vieja Escolástica", could finally be envisaged and appreciated in his intellectual complexity. ${ }^{51}$ Nevertheless, the historiography on these and other important methodological issues - critical for distinguishing the stages in the history of knowledge production in Salamanca and beyond - did not go too far and instead simply regurgitated general statements. Was this progressive abandonment of Boetius's translations of Aristotle and the incorporation of Florentine humanist translations in the Salmantine - and later, American - curricula only a philological matter? How important were those changes which were first introduced in the arts curricula for the faculties of theology, law, and medicine? Did the new translations also contribute to a deep renewal of juridical and political thought? Unfortunately, the existing literature on the School of Salamanca does not provide answers to these matters or other important methodological issues located at the intersections of the disciplines, which, as Thomas Duve states in the opening chapter of this volume, deserve more attention than has been afforded by traditional historiography. In this, I follow Duve's idea that the School of Salamanca should not be defined as a purely theological or juridical school, but as a school that produced knowledge globally and in many different areas. Folch's chapter illustrates this point well, showing the common interests of "Mexican" Augustinians who trained at Salamanca (Vera Cruz and Rada) not only in theology, law, and politics, but also in disciplines such as astronomy, cosmography, and architecture; it also demonstrates that the kind of universal interest which distinguished the Renaissance "intellectual" (among whom Florentine figures such as Leonardo Bruni have been better studied) was present in Salamanca and Mexico.

This line of interpretation should be pursued in future research against the fixed and reductionist approaches that prevail in the classical literature about the School.

De Indis and De dominio infidelium Confronted: Similar Methods and Questions, Different Authorities and Answers

The contrast between the juridical treatises of Vera Cruz and Vitoria allows us to show the employment of a similar argumentative methodology and the

51 Monsalvo Antón, "Impulso institucional e intelectual del Estudio, c. 1380-c. 1480", 99. 
sharing of some important epistemic premises as remarked upon by Duve as the basis of an epistemic community. Beyond those similarities however, Vera Cruz paid much more attention than Vitoria to the specific characteristics and needs of indigenous peoples. This meant that, despite sharing important assessment criteria, Vera Cruz argued in a way that was more empathetic to the specific cultures of the natives of New Spain and to local practices.

When comparing De dominio infidelium et iusto bello, the lesser-known relectio of Vera Cruz, and De Indis, Vitoria's famous relectio, the reader is struck by the great similarity between the formal structures of the two texts. From the beginning, it is clear that Vera Cruz based the organisation of his argument on Vitoria's method: both began with an overview of the dubia/quaestiones and these were then evaluated with an axiom or general thesis from a well-known and authoritative biblical quotation, expressing a clear biblical imperative. Vitoria began by focusing on the universal obligation to preach the Gospel in Matthew 28:19 ("Docete omnes gentes, baptizantes eos in nomine Patris, et Filii, et Spiritus Sancti" [Teach all the peoples, baptising them in the name of the Father, and the Son, and the Holy Spirit]), whereas Vera Cruz focused on the equally important and well-known imperative of Matthew 22:21 to obey secular and divine authorities ("Reddite Caesaris Caesari et quae Dei sunt Deo" [Render unto Caesar that which is Caesar's and to God that which is God's]).

These biblical quotations and imperatives that testified to the indisputable patrimony of the Church served to give rise to some doubts and questions in Vitoria and Vera Cruz. At the very beginning of their texts, both authors emphasised that they would address the radically new controversies which had arisen in the wake of the need to enforce classical biblical imperatives in a changing context, marked by recent and unforeseen events. Although Vitoria and Vera Cruz embarked on their justifications similarly in general terms, a difference between their perspectives - which influenced the development of their arguments - is soon observed. While Vitoria highlighted the historicalchronological novelty of the disputatio that had arisen from the need to satisfy the imperative of universal evangelisation in a problematic and still unknown New World, which had only been discovered 40 years previously, ${ }^{52}$ Vera Cruz sought to locate his study much more precisely by making continuous use of demonstrative adjectives to express his close proximity to the doubts that had arisen "in istis partibus" [in those places] and that were now under

$5^{2}$ "Et tota disputatio et relectio suscepta est propter barbaros istos novi orbis, quos indos vulgo vocant, qui ante quadraginta annos venerunt in potestatem hispanorum, ignoti prius nostro orbi", Vitoria, De Indis, 2. 
evaluation. ${ }^{53}$ The very concrete references Vera Cruz made to specific native populations, political structures and offices (viceroy, oidores), and practices of the encomienda system indicated from the very beginning that he was reevaluating the questions that Vitoria had examined from Spain but which were still set in a vague and undefined New World to the older master. As if to underscore that contrast, Vera Cruz repeatedly referred to himself as an eyewitness in the very specific area of New Spain. For example, the second doubt closed with a bitter denunciation of the encomenderos' wilful neglect of the spiritual good of the Indians, reflecting the strong connection between Vera Cruz's theoretical reasoning and life experience that was absent in Vitoria's De Indis.

I speak from experience. I know not a few men (otherwise noble in the eyes of the world, and would to heaven in the eyes of Christ for whom the only nobility is virtue), the walls of whose homes are covered with precious silk tapestries, boast gold and silver service for food and drink, whose beds, if not ivory, are covered with pure silk, enjoy a numerous retinue of servants, have countless and costly changes of clothes, and even resplendent harness for their horses, but in the church of these natives from whose tribute they obtain all they have, neither chalice nor the altar furnishings necessary to say Mass can be found. Finally, I cannot write a word of what I am stating without the deepest concern, for what I have written I beheld not in one or two villages but in many. God grant that such encomenderos undergo a change of heart! ${ }^{54}$

Almost one-third of Vera Cruz's relectio addressed very specific practical matters related to the concrete way in which Spaniards effectively exerted the dominium they had acquired over the natives after the wars and conquests of the 1520 . In this way, doubts I to $\mathrm{V}$ and question VI raised a set of problems that had otherwise been almost completely absent from Vitoria's pioneering evaluation of Spanish dominium over American peoples. Doubt I detailed the legal and in foro conscientiae conditions that had to be fulfilled by any Spaniard who took tributes from the natives. In doubt II, as has already been mentioned, Vera Cruz underlined the encomenderos' obligation to instruct the natives in the Christian faith and complained bitterly about the spiritual neglect of many

53 "Ponuntur nonnulla dubia quae sese offerunt in istis partibus. Primum. Primo est dubium utrum illi qui habent populos in istis partibus absque titulo, possint iuste tribute recipere, an teneantur ad restitutionem ipsorum et resignationem populi", Vera Cruz (Heredia), De dominio infidelium, 1.

Vera Cruz (Burrus), De dominio infidelium, 135 . 
Spaniards who were totally indifferent to their salvation. In doubt III, Vera Cruz examined whether encomenderos could occupy the lands of the natives through an exhaustive analysis of the royal legislation concerning agricultural fields, farms, ranches, and uncultivated and communal lands. The precision with which Vera Cruz analysed this juridical topic inspired the famous Mexican legal historian Silvio Zavala to call him the "primer maestro de derecho agrario en México". ${ }^{55}$ It is clear that such a profound legal and practical insight could only be achieved through direct familiarity with the people and practices of the place and by living there for a number of years. Vera Cruz entered into a similar technical discussion in doubt IV in an attempt to stipulate the legal and moral criteria encomenderos had to respect when they fixed the taxes that were to be levied in different places.

In doubt $\mathrm{v}$, the abstract approach of Vitoria and the practical outlook of Vera Cruz began to interact when the Augustinian friar raised the question of whether the Indians could be considered true owners of the land. The hypothetical impediments of infidelity and sins against natural law were discarded by Vera Cruz just as they had been by Vitoria. The biggest difference between them was the empirical knowledge and experience Vera Cruz had amassed visà-vis native political institutions and customs, which provided him with the means to discard some arguments of other Spanish jurists that invalidated any possible native claims to private and jurisdictional dominium. Vera Cruz particularly rejected the alleged inability of the natives to organise true republics by explaining in rich detail what he had learned from the oldest inhabitants of Michoacán about the complex and prudent practices of the Purépecha people for electing their local rulers or carachaca pati. ${ }^{56}$ The use of native political terminology showed how well-acquainted Vera Cruz was with the pre-Hispanic institutions and customs of the region.

55 Zavala, Fray Alonso de la Veracruz: primer maestro de derecho agrario.

56 "Libet hic ponere modum quem habebant in provincia de Mechoacán in electionem dominorum, ut audivi a maioribus [...]. Statim ut in aliquo oppido regni moriebatur dominus, qui vocabatur carachaca pati, ex populo celeriter mortis nuntium regi per nuntium deferebatur; et statim, audita morte, dicebat rex illis nobilibus et primoribus qui in sua curia et palatio errant, ut ipsi convenirent et ad invicem inter se conferrent qui scilicet constituendus dominus in tali populo, etc. Et ipsi ad invicem conferentes iuxta conditionem populi alique nominabant; et post ultimam sententiam ad quattuor illos praecipuos deferebatur; et sic, ipsis definientibus, intrabant ad regem et dicebant se tale definiisse, et sic destinabantur aliqui ad hoc deputati, qui deferebant ipsum ad populum, qui et publice denuntiabant omnibus quod talis esset ibi dominus constitutus, et quod omnes ei praestarent oboedientiam [...]. Ex istis constant apertissime inter eos fuisse regimen ad bonum reipublicae, et quod veri erant domini", Vera Cruz, De dominio infidelium (Heredia), 58 . 
Finally, in question VI, Vera Cruz presented some tricky legal subtleties, many of which were practiced by the Spanish settlers to buy or obtain lands belonging to native communities, and assessed them according to royal laws and the prevailing moral-theological normativity. It is not until question VII that De dominio infidelium takes a more Vitorian format, examining the classical quaestiones of whether the emperor could be considered the lord of the world and the owner of his vassals' goods in questions VII and VIII. The pontifical ambitions to a supreme and uncontested dominium were discarded in question IX and, employing a clearly Salmantine perspective, the valid and invalid titles to wage war against the natives of Mexico were discussed in questions $\mathrm{X}$ and $\mathrm{XI}$.

Each of these doubts and questions were raised and resolved by Vera Cruz according to the same scholastic for and against method that had been employed by Vitoria and such great medieval masters as Thomas Aquinas. Before analysing the heart of the question under discussion, he made some preliminary observations or distinctions that were not only important but also helped the author to frame and contextualise the issue he was resolving. These elements were introduced in the relectiones of Vitoria and Vera Cruz through expressions like "ante omnia videtur" [before all seems], ${ }^{57}$ "pro solutione huius quaestionis est considerandum" [must be considered to resolve this question], ${ }^{58}$ "pro solutione breviter notandum" [to quickly note the solution], ${ }^{59}$ "secundum est considerandum" [must be considered accordingly]. ${ }^{60}$

The author made use of biblical excerpts, theological and juridical authorities, and reasonable considerations - among other strategies - in the second step, and presented arguments in favour of an opinion contrary to the one he ultimately defended in the third step of his argumentative exercise, which he did by appealing to more authorities and citing more convincing arguments. The proposition the author defended was always divided into major and minor parts that were substantiated separately. These parts, which were individually examined, allowed a series of conclusions to be drawn in turn. Such a complex structure became even more intricate with the introduction of one or more corollaries, in which specific cases or issues indirectly related to the question initially raised were also evaluated. The objective of this argumentative approach was to clarify beyond doubt if the solution offered was valid and/ or just.

57 Vitoria, De Indis, 4.

58 Vitoria, De Indis, 5.

59 Vera Cruz (Heredia), De dominio infidelium, 1.

6o Vera Cruz (Heredia), De dominio infidelium, 3 . 
This method of argumentation to resolve doubts and cases was not only deeply related to the logical, propaedeutic education received by both Vitoria and Vera Cruz in Paris and Salamanca, but also to the classic Aristotelian concept of justice, in which the concrete exercise of justice or impartial judgment resulted from positioning oneself between two extremes. ${ }^{61}$ Even in cases where someone's personal judgment coincided with an opposing view, a thorough discussion of the arguments in favour of that contrary position was expected in the evaluation. The willingness to make concessions to contrary positions was also welcomed because it showed the magnanimity that distinguished a prudent and wise man from a merely erudite one.

Vitoria and Vera Cruz, along with most members of the School of Salamanca - theologians and jurists -, applied a concept of justice that went beyond the simple application of the letter of the law. The attitude of Epikie i. e. upholding the ideals of preserving and interpreting the spirit of the law ,${ }^{62}$ was far more important to those entrusted with the task of imparting justice than the universal application of norms or criteria in any given case. The latter attitude was difficult, even inadequate, given the differences that prevailed in a world with great diversity of traditions, customs, and peoples. The sic et non [yes and no] argumentative method on the other hand perfectly corresponded to that idea of justice: the evaluation of different approaches to a certain problem, related preliminary distinctions, doubts, tentative answers, refutations, and provisional conclusions aimed at avoiding absolute solutions in the administration of justice, a virtue whose practice was considered necessarily relational, prudential, and casuistic. ${ }^{63}$

This method nevertheless had an important counterpart which must be examined in order to understand Salamanca's philosophical, juridical, and theological discursive community: given that the application of the general criteria of justice differed according to time, regions, person (especially quality of person), custom, and other circumstances, the results of distinct argumentative exercises could be dissimilar, even if the same methods were applied

61 López Lomelí, "La polémica de la justicia en el tratado De dominio", 134.

62 For the case of Vitoria's Relectiones and commentaries to the Summa theologiae (De legibus, De iustitia), see Cruz Cruz, "Die Epikie bei Vitoria".

63 Focusing primarily on juridical texts and authors, Tau Anzoátegui has also considered Derecho indiano's perspective on justice as closely connected to the "definición aristotélico-tomista": "La justicia no se entendía como la mera aplicación de un precepto legal a una situación planteada, sino como la solución adecuada del caso, apoyada en un amplio y variado aparato normativo integrado por leyes, costumbres, obras jurisprudenciales, prácticas, etc. Se admitía el arbitrio del juez en la búsqueda de la equidad", Tau Anzoátegui, "La idea de derecho en la colonización española de América", 31. 
and similar issues addressed. That was precisely the case when Vera Cruz wrote from the distant Augustinian missions in Mexico and re-examined the very same questions - in a more practical and specific manner - that Vitoria had answered in a theoretical and erudite way 15 years previously, speaking before the Salmantine academic community.

In a different context, some of the positions and authorities rejected by Vitoria regained a certain legitimacy or were seen in a different light. The issue of forced conversion is perhaps the clearest example of a split in opinion between the Salamanca masters and their missionary students. In fact, while the use of coercive measures to fulfil the evangelical precept "compelle eos intrare"64 [force them to enter] was categorically rejected by Vitoria and other scholars in a Salmantine academic context where the authority of Thomas Aquinas (Summa Theologiae, $\mathrm{II}^{\mathrm{a}}-\mathrm{II}^{\mathrm{ae}}$, q. 10, arts. $\left.8-9\right)^{65}$ prevailed, it was often considered differently in the missionary context overseas. For example, the Jesuit José de Acosta, who drew on Vitoria, Soto, and other Salamanca masters on many issues, distanced himself from them over the debates on missionary methods in the Americas. The absolute rejection of forced conversion, which Vitoria had considered to be a common conclusion that civil and canon lawyers would have drawn, ${ }^{66}$ had to be re-evaluated or implemented in a circumscribed manner in the new context where many long-planned and onerous preaching initiatives - aimed at converting indigenous people to Christianity encountered the fierce resistance of hostile populations or culminated in the abrupt and inexplicable departure of the instructed "infidels" and "neophytes". Explaining the different approach of the Society's missionaries in the late 158 os with such examples, Acosta justified the implementation of some coercive conversion measures on the most fierce "bárbaros" - like the ones inhabiting Florida, Brazil, southern Chile, or the northern regions of Mexico (Chichimeca) -, arguing that they were "gentes acostumbradas a vivir como

\section{$64 \quad$ Luke 14:23.}

65 Aquinas, Summa Theologiae, $88-91 . \mathrm{II}^{\mathrm{a}}-\mathrm{II}^{\mathrm{ae}}$, q. 10, a. 8 is precisely the reference given by Vitoria in De Indis: "Quantucumque fides annuntiata sit barbaris probabiliter et sufficienter et noluerint eam recipere, non tamen hac ratione licet eos bello persequi et spoliare bonis suis. Haec conclusio est expressa S. Thomae (Secunda Secundae, quaest. 10, art. 8), ubi dicit quod infideles, qui nunquam susceperunt fidem, sicut gentiles et iudaei, nullo modo sunt compellendi ad fidem", Vitoria, De Indis, 65 .

66 "Et est conclusio communis doctorum etiam in iure canonico et civili. Et probatur, quia credere est voluntatis. Timor autem multum minuit de voluntario (tertio Ethicorum) et ex timore servili dumtaxat accedere ad sacramenta Christi sacrilegum est", Vitoria, De Indis, 65-66. 
bestias, sin pactos y sin compasion" and could not be instructed in the same way as true "hombres de razón".67

Vera Cruz, the key figure in the initial missionary campaigns of the Augustinian order in the lands inhabited by the nomadic Chichimeca peoples in Central and Northern Mexico, shared and prefigured Acosta's approach. Leaving aside the authority of Aquinas and Vitoria on forced conversions, he subscribed to the contrary view of Duns Scotus and justified a war against an infidel population that, despite having been properly indoctrinated in the "true faith" - that is, given sufficient time and instructed by expert and benevolent preachers -, rejected the prospect of converting to Christianity with a guilty stubbornness. Vera Cruz - inappropriately - called this kind of violent compulsion "coactio indirecta" [indirect coercion].

What I want to say in this conclusion is that if any nation of unbelievers which never heard about Christ has the faith sufficiently proposed and preached to it so that those who listen to the explanation of the faith would sin in not assenting to it who earlier were excused through invincible ignorance from believing; since its tenets were either not explained at all or were not sufficiently explained to that they were bound to believe; such persons strictly speaking, and precluding scandal and apostasy- may be coerced into accepting baptism and the faith, not so that they pretend to believe but that they will want to believe with all their heart what they formerly rejected. This is termed indirect coercion. ${ }^{68}$

This was undoubtedly a major departure from Vitoria's De Indis, which considered the rejection of Christ to be an illegitimate title (the fourth invalid title), ${ }^{69}$ and which was only used by conquerors and plunderers to try to cover their misdeeds with theological alibis. Interestingly enough, in this paragraph, Vera Cruz invoked the same fragment of Scotus's Commentaries to the Fourth Book of the Sentences (Lib. IV, dist. 4, quaestio 9) which Vitoria had considered inapplicable to the American pagans, ${ }^{70}$ in effect confirming this volume's perspective

67 Acosta, De procuranda indorum salute, book II, chapter viII, vol. I, 308-309.

68 Vera Cruz, De dominio infidelium (Burrus), 389.

69 "Et ideo quartus titulus praetenditur, quia scilicet nolunt recipere fidem Christi, cum tamen proponatur eis et sub obtestationibus admoneantur, ut recipient", Vitoria, $D e$ Indis, 54 .

70 "Et quamvis Scotus (in Quartum, dist. 4, quaest. ult) dicat quod religiose fieret, si infideles cogerentur a principibus minis et terroribus ad fidem, hoc tamen non videtur intellegere nisi de infidelibus qui alias sunt subditi principum christianorum, de quibus postea 
on the School of Salamanca as a discursive community that shared methods, points of reference, and authorities, but occasionally diverged on important doctrinal and practical matters.

This is the conclusion to be proved at present, and let no one take offence at its novelty; Scotus alludes to it in 4. d., 4 question, as also others. By God's grace, we shall make it so clear that it will meet with approval [...]. Fourthly, as approved authorities hold that the children of unbelievers even against the will of their parents, may be baptized (since one can act against an inferior in favor of a superior and carry out his will), accordingly, also, in the present instance: in order to carry out the order of the superior the inferior may coerce his subjects into accepting baptism. [Scotus, 4. dis. question 9] $]^{71}$

This quotation clearly shows that Vera Cruz was conscious of the polemical and minority character of the theological and juridical position he held in this case. Considering how his former masters and fellow students would see the theological and juridical stance adopted by Vera Cruz with regard to forced conversion, he even offered his apologies ("nullus offendatur ex novitate" [no one could be offended by the novelty] $)^{72}$ to those readers who would feel offended by his opinion. In any case, this conscious breach with Aquinas and Vitoria on the same matter did not prevent Vera Cruz from implementing his own approach. As Egío shows in his chapter on Speculum coniugiorum, according to Vera Cruz, casuistic analysis had to prevail in cases of disagreement between classical authorities and even an extremely marginal position in the pre-existing literature could prove to be the adequate solution under new and unforeseen circumstances. He believed this to be the case in his examination of the validity and appropriateness of forced conversions in the New World, a complex dilemma which had to take account of not only the benefit of present generations, but also the spiritual good of following ones. Since the persistence of a certain people in an imposed but salvific faith and the risks of a hypothetical future apostasy were a matter of prudential and casuistic estimation, any fixed solution or criteria had to be avoided in favour of case-bycase assessments.

dicitur. Barbari autem non sunt tale. Unde puto quod nec Scotus hoc assereret de barbaris istis", Vitoria, De Indis, 66-67.

71 Vera Cruz, De dominio infidelium (Burrus), 389 and 395.

72 Vera Cruz, De dominio infidelium (Burrus), 388. 
Thus, granting that the Catholic king, in enacting these laws to induce them to embrace the faith, would realize that these laws would not benefit at present those now living, yet could foresee that in the future they would benefit the present generation, their children and their descendants, one might hold that such a law is fair, such correction is just and such inducement prudent. It is not possible to determine all such matters theoretically, but they must be left to the decision of an upright person, who, after he has weighed all factors, will determine what is fair and just. ${ }^{73}$

A lot could be said about Vera Cruz's prescription of indirect coercion in the Mexican context. ${ }^{74}$ Indeed, it was the legitimate title for waging war against the natives to which the Augustinian friar dedicated his longest explanation in doubt XI, which was the section in his relectio that listed and assessed the different, valid motives for conquest. The justification of indirect coercion made up a quarter of the doubt's length. For the purposes of our analysis of $D e$ dominio infidelium, which in many ways characterises the influence of Vitoria and the better known masters of the School of Salamanca in America, it is important to note that forced conversion was only one of the friction points in the problematic cultural translation of teachings that had previously been studied in Salamanca.

Tribute was as controversial a matter as it was important to the administration of the Spanish empire, as can be seen in the differing approaches of Vitoria and Vera Cruz. Conscious of the fierce clash that could result from his meddling in these delicate matters - which cut to the very heart of ecclesiastical and secular jurisdiction -, Vitoria did not dare to address taxation issues in his relectiones over asuntos de Indias. In De Indis, the famous Salmantine master merely stated that the kind of jurisdictional dominium held by the emperor in the Indies did not make him the owner of the possessions - goods and lands (praedia) - of his new vassals, and that just like his Iberian subjects, indigenous people in the Americas held dominium over their goods (dominium rerum suis), which could not be arbitrarily expropriated to enrich the Spanish settlers. ${ }^{75}$

73 Vera Cruz, De dominio infidelium (Burrus), 403.

74 See the article of Heredia Correa that is dedicated to the topic, "Coacción para la fe".

75 "Dato quod Imperator esset dominus totius mundi, non ideo posset occupare provincias barbarorum et constituere novos dominos et veteres deponere et vectigalia capere. Probatur, quia etiam qui Imperatori tribuunt dominium orbis, non dicunt eum esse dominum per proprietatem, sed solum per iurisdictionem, quod ius non se extendit ad hoc ut convertat provincias in suos usus aut donet pro suo arbitrio oppida aut etiam praedia. Ex 
We know that Vitoria added other details to that short and general prescription in the courses he dedicated to Aquinas's I $^{\mathrm{a}}{ }^{\mathrm{II}} \mathrm{I}^{\text {ae }}$ between ${ }^{1527-1529}$ and 1534-1537. ${ }^{76}$ In all likelihood, Vera Cruz heard the first systematic review of the $\mathrm{II}^{\mathrm{a}}-\mathrm{II}^{\mathrm{ae}}$ from 1527 to 1529 where he probably learned that, for Vitoria, the overtaxation of "infidel vassals" who were subjects of Christian princes was not only legitimate but even prescribed as a sound policy for fostering voluntary conversions. ${ }^{77}$ Writing from Mexico where he could directly see the pernicious effects of the imposition of such unfair rates of taxation, forcing the natives to bear the heavy burden of the royal fisc, Vera Cruz rejected the a priori pious recommendation of his teacher. In his opinion, all native vassals should always have a lighter tax burden under their new Christian rulers than they had under their former natural lords so that both neophyte and infidel subjects could appreciate the justice and magnanimity of the Spanish kings. ${ }^{78}$

In his commentaries on Aquinas's $\mathrm{II}^{\mathrm{a}}-\mathrm{II}^{\mathrm{ae}}$, Vitoria used an approach to property and taxation - which both Aquinas and his commentators considered as a way of transferring the dominium of certain goods from the original owner to another - that also left the emperor, the kings, and other public authorities much room for manoeuvre to seize the property of their subjects if a certain necessity or rational cause - linked to the common good of the republic - could be used to justify the expropriation. ${ }^{79}$ Vera Cruz had witnessed the depredations in Mexico that resulted from such an arbitrary

dictis ergo patet quod hoc titulo nec possunt hispani occupare illas provincias", Vitoria, De Indis, 42.

76 Langella, "Fuentes manuscritas de la Escuela de Salamanca", 274.

77 "De infidelibus subditis idem est iudicium sicut de aliis christianis. Non licet ab eis capere bona sicut nec a christianis, nisi ordine iuris, quia ex eo quod sunt infideles non amittunt ius bonorum suorum. Bene tamen licitum est in favorem fidei plus cogere et gravare illos tributis solvendis quam christianos, ita quod si christiani solvent decem, quod solvant ipsi quindecim, dummodo non importabiliter", Vitoria, Beltrán de Heredia, Comentarios a la Secunda Secundae, q. 62, art. 8.

78 "Immo sequitur quod minora tributa debent exigi nunc a rege Catholico quam olim a tyranno ut sic iustitia dominio appareat omnibus, et in hoc vigilare debent qui locum tenent ipsius regis Catholici et imperatoris, ut tributa sint minus gravia quam erant illa quae olim. Alias, si ante tyrannicum erat dominium ob excessum, et modo sic exiguntur tributa vel amplius, erit et dominium et tyrannicum et iniustum quale erat primum", Vera Cruz, De dominio infidelium (Heredia), 172.

79 "Hoc dico propter reges, qui non possunt sine causa rationabili sibi appropiare aliquod thesaurum. Bene propter rationabilem causam, scilicet propter necessitatem reipublicae, alias non, quia esset tyrannicum privare homines de illo quod est de jure naturali", Vitoria, Beltrán de Heredia, Comentarios a la Secunda Secundae, q. 66, a. 1. The most systematic exposition of Vitoria's ideas on tributes and taxation can be found in his commentary to Aquinas $\mathrm{II}^{\mathrm{a}}-\mathrm{II}^{\mathrm{ae}}, \mathrm{q} .62-63$. 
regulatory framework: under the guise of necessity, the common good, or the protection of the land, different authorities introduced new tributes alongside increasing the ones that already existed. Therefore, he tried to circumscribe Vitoria's appeal to necessity - tenable in theory but inappropriate in practice for a region such as the one he was evangelising - to the sole potestas of higher authorities (such as emperors, kings, popes, and councils), denying minor authorities the ability to make a similar claim. ${ }^{80}$ Curiously, in his approach to taxation, Vera Cruz appealed to the authority of a more ancient Salamanca master, El Tostado - whose influence is evident in all Vera Cruz's writings -, to correct or introduce some nuances in Vitoria's Thomistic approach.

Vera Cruz referred to El Tostado's (Abulensis) extensive commentary on 1 Kings, 8:11-17. This biblical passage had been invoked throughout the history of Christianity, and particularly in the Thomist tradition, to justify the adoption of typically tyrannical measures - such as the forced levy of taxes and recruitment - under the guise of exceptional circumstances, extreme need, or common good. 1 Kings, 8: 11-17, as interpreted in Aquinas's Summa theologiae $^{81}$ and in the influential exegetical writings of Nicolas de Lyre, was elaborated by the mid-14th century in precisely that manner. With the characteristic Aristotelian and republican tone that distinguished both his political treatises and biblical commentaries, ${ }^{82} \mathrm{El} \mathrm{Tostado}$ protested against this line of interpretation, claiming that there was no basis to treat vassals as servants or slaves or

8o " $[. .$.$] quod si extrema esset necessitas, posset disponere et deberet et teneretur ad bonum$ commune; quae tamen potestas non esset in aliis. In tertio argumento tangitur de potestate imponendi tributa sibi subditos, quam damus imperatori, sicut et concilio et summo pontifici, sicut supra dictum est et inferius dicetur. Tributa enim imponere potest sibi subditis; moderata tamen in quantum sufficiunt ad portandum onus imperio, pro quanto conservatur bonum commune. Sed tamen ex hoc habeat imperator talem potestatem, non sequitur quod ipse sit dominus et proprietarius rerum subditorum suorum", Vera Cruz, De dominio infidelium (Heredia), 100.

81 "Praeterea, sicut regnum est optimum regimen, ita tyrannis est pessima corruptio regiminis. Sed Dominus regi instituendo instituit ius tyrannicum: dicitur enim I Reg. vIII: Hoc erit ius regis qui imperaturus est vobis: Filios vestros tollet, etc. Ergo inconvenienter fuit provisum per legem circa principum ordinationem [...]. Ad quintum dicendum quod illud ius non dabatur regi ex institutione divina; sed magis praenuntiatur usurpatio regum qui sibi ius iniquum constituunt in tyrannidem degenerantes, et subditos depraedantes. Et hoc patet por hoc quod in fine subdit: Vosque eritis ei servi: quod proprie pertinent ad tyrannidem, quia tyranni suis subditis principantur ut servis. Unde hoc dicebat Samuel ad deterrendum eos ne regem peterent: sequitur enim: Noluit autem audire populus vocem Samuelis. Potest tamen contingere quod etiam bonus rex, absque tyrannide, filios tollat, et constituat tribunos et centuriones, et multa accipiat a subditis, propter commune bonum procurandum", Aquinas, Summa theologiae, $\mathrm{I}^{\mathrm{a}}-\mathrm{II}^{\mathrm{ae}}, \mathrm{Q}$. 105, art. 1, 262-263. 
for expropriating their goods and disposing of their bodies by force ${ }^{83} \mathrm{~A}$ clear distinction should thus always be made between a perverse and intolerable tyrannical regime and proper royal kingship (principatum regale). Vera Cruz firmly adhered to this line of biblical exegesis and republican political thought in his De dominio infidelium, appealing to the authority of El Tostado from the distant Viceroyalty of New Spain to criticise the usual seizure of native lands and goods which were then transferred to Spanish settlers under the pretext of necessity. For Vera Cruz, considering that most of those Spaniards did not contribute to the common good but, on the contrary, inflicted economic and moral damages on the natives and prevented them from converting to the faith, such expropriations of private and communal lands - along with the forced labour of the natives as a kind of tribute - could never be justified without the "expressa voluntate" [express will] of the local inhabitants.

It also follows that if the Spaniards continued presence in the New World proved detrimental and scandalous to its natives and hindered their conversion to the faith because of the bad example which the Spaniards give, or for any other just reason, it follows, I say, that in such a case there could be no justification of a gift made from the communal property without the express consent of the natives themselves. Rebuttal to the arguments presented. Answer to the first arguments. There have not been wanting jurists who, convinced by the passage cited from Scripture [Kings, 8: 11-17], hold that the emperor is the lord of the world and has power over all in the kingdom not only on jurisdiction but even on ownership, and, accordingly, may at will dispose of everything $[\ldots]$. Nicholas de Lyre in the commentary to the passage cited says that certain powers of the king are considered in the light of some

83 "Opinio Lyrani de iure Regum confutatur. Quaest. $X X$. Sed dicendum est, quo dista, quae ponuntur hic, non sunt iura Regum debita, ut ipsi exigere possint illa a subditis. Nec stat distinctio, quod quaedam illorum pertineant ad Regem existentem sine necessitate, \& omnia pertineant ad Regem existentem in necessitate: nam nulla necessitas Regis esse potest, pro qua licitum sit, quod ipse reducat in servitutem subditos suos infra tamen dicitur: Vos eritis ei servi, \& clamabitis; ergo non poterat Rex aliquo modo ista exigere, nam Rex illa iuste exigit, quae pertinente ad principatum regalem manentem in viribus suis; cum autem tranfierit principatus regalis in tyrannidem, est iam perversissima politia: ergo non poterit Rex exigere ea, quae pertinente ad tyranidem; sed nulla maior potest ese species tyrannidis, quam quod Rex servos efficiat subditos suos, ergo nullo casu hoc licet. Item multa alia sunt hic, quae pertinente ad iniuriam, \& non prosunt ad commune bonum regni.s.q Rex faceret filios Israelitarum aratores agrorum suorom, \& messores segetum, \& fabros armorum, sed ista fieri non possunt nisi ad utilitatem privatam Regis, \& cum gravi damno subditorum, ergo nullo modo ista Rex potest exigere", Fernández de Madrigal, Commentaria in Primam Partem I. Regum, Venezia 1615, I. Regum Cap. vilI, 154-155. 
necessity and others prescinding from it, and adds that in case of necessity these powers are extended to include everything just as the part naturally sacrifices itself for the good of the whole. But, nonetheless, this opinion does not please all, for the Avilan on the same passage, question 17 , says that there are certain limitations to his power, inasmuch as it is by no means permissible for the king ever to force a person into slavery - no necessity can exist by which it would be allowed for the king to do this. Hence the Avilan holds that such are granted not as a right of the king but as certain evils which the king can effect in regard to his subjects due to the extent of this power. ${ }^{84}$

"Localising" Vitoria: The Emergence of the Facts and the Inapplicability of Vitoria's Secular Titles for Just War

As Jose Luis Egío argues in his comparison between Alonso de la Vera Cruz's Speculum coniugiorum and the writings of Vitoria or Soto on the sacraments in the next chapter, it is clear that, as a result of his experience in New Spain, Vera Cruz tended to deal with doubts and problematic matters with a higher degree of flexibility, avoiding excessive severity against many local indigenous customs and sexual practices that would not have been tolerated in Europe (from repudiation to masturbation) as far as possible. The same occurred in $D e$ dominio infidelium, discussed here.

As mentioned above, the originality of Vera Cruz's relectio lay in his ability to engage with the rather theoretical and approximative questions of Vitoria with a great degree of specificity by including empirical evidence. Having lived for almost 20 years among different indigenous peoples in Central and Northern Mexico, Vera Cruz was better equipped than Vitoria, whose writings and reflections had been carried out as an armchair scholar in Salamanca, to produce a practical and credible knowledge and to discern the righteous truth ad casum [for the case]. By 1554-1555, he had already gained solid knowledge not only of the colonial laws but also of the ways in which they were put into practice by different royal officials in the Western Indies. His knowledge of these hitherto mysterious "Indians", whom Vitoria was unsure whether to classify as amentes [stupid, senseless] or not, ${ }^{85}$ was also much deeper, having learned about

84 Vera Cruz, De dominio infidelium (Burrus), 281-283.

85 "Alius titulus posset non quidem asseri, sed reuocari in disputationem, \& videri aliquibus legitimus. De quo ego nihil affirmare audeo, sed nec omnino condemnare: \& est talis, Barbari enim isti, licet ut suprà dictum est, non omnino sint amentes, tamen etiam parum distant ab amentibus", Vitoria, De Indis, 97. 
Purépecha and Nahua histories and cosmovision, family and social traditions, and customary political structures from his own indigenous neophytes. These elements constituted the core of Vera Cruz's approach to arguing with and against Vitoria. Using the advantage of his empirical knowledge, Vera Cruz did not hesitate, for example, to absolutely refute Vitoria's speculations over the hypothetical amentia of the Indians, which would have rendered them unable to have dominium over goods and jurisdictions.

We deny that the natives of the New World are so dull and witless as some imagine; in fact, although primitive, they have their own form of government and customs by which they live; they also have through oral tradition from their forefathers laws by which they judge and plan rationally; they carry on inquiries, they consult with each other; all of which are actions not of fools and insane but of sagacious persons. And, as among us, not all are outstanding for wisdom and so eminent that they can direct others but rather such are few, others must obey officials and rulers, so also among these natives as in every community, regardless how insignificant, there are those, who, endowed with ability, are evidently fitted by their intelligence and sagacity to govern the rest. And, thus, before the coming of the Spaniards they lived peacefully in their state which could not have subsisted if they were so infantile and unintelligent. ${ }^{86}$

Following the same experiential criteria, Vera Cruz evaluated the main titles claimed by Vitoria to justify the war against the Indians in question XI of his De dominio infidelium. Notwithstanding how the affinities and differences between the approaches of Vitoria and Vera Cruz have been determined and explained in more recent studies, the key question should not simply relate to whether Vera Cruz agreed with his teacher or abruptly broke with his approach. ${ }^{87}$ By and large, Vera Cruz's relectio continuously balanced the for

86 Vera Cruz, De dominio infidelium (Burrus), 379-381.

87 See, for example, the opposing views of two of the main experts on Vera Cruz's thought, Rovira Gaspar, who emphasised the great affinity between the positions of Vera Cruz and Vitoria (“Asímismo puede advertir también que Alonso siguió en general las propuestas que Vitoria manejó en la parte tercera de su relección Sobre los indios, al tratar y exponer los títulos legítimos por los cuales los bárbaros pudieron venir al dominio de los españoles. Pero es necesario advertir que las propuestas de Vitoria las plantea Alonso como dudas. En la cuestión vi la tesis tercera coincide con Vitoria. Lo mismo ocurre en la tesis VI, incluso maneja el mismo ejemplo citando a los tlaxcaltecas y mexicanos. Asímismo las tesis duodécima, decimotercera, decimocuarta y decimoquinta parecen copiadas del texto de Vitoria", Rovira Gaspar, "Relación entre Sobre los indios y De iusto bello contra indos", 177), and Velasco Gómez, who considered Vera Cruz more radical than Vitoria - and Soto -, 
and against arguments with a battery of other, seemingly contradictory arguments that, if removed from their proper place in the logical exposition of the relectio, could give rise to a myriad of erroneous interpretations, as can be observed from the conflicting interpretations of De dominio infidelium.

In general terms, it is possible to say that, apart from the delicate matter of the legitimacy of forced conversions (see previous section), Vera Cruz arrived at the same juridical and theological conclusions as Vitoria in his evaluation of the legitimate titles of just war. In doubt XI of De dominio infidelium, the war against indigenous peoples was considered just if: 1) a certain pagan people refused to adhere to the preaching of Christian missionaries about the Gospel in a peaceful and adequate manner, or impeded the churchmen from travelling and establishing contact with other "infidel populations"; 2) the natives were converted to Christianity but there was a well-founded fear that those neophytes would not keep their Christian faith, especially if their natural pagan lords were not removed from office and replaced by Christian authorities; 3) tyrannical native rulers oppressed their vassals in an intolerable manner; 4) anthropophagy, ritual cannibalism, or human sacrifice were practiced by those infidel populations; 5) an allied people, waging just war against its offenders, asked the Spaniards for help; 6) a certain community or nation was voluntarily subjected to the Spaniards, recognising the king as their own supreme lord, to that extent that the previous sovereign could legitimately effect such a transfer of dominium if his vassals freely consented or if that native ruler renounced his throne and freely handed it over to a Christian monarch, looking to the greater good of his own community which he himself was unable to achieve; 7) the natives, who had not been harmed by the Spaniards, prevented them from travelling to their lands, engaging in trade, or establishing mines.

and cast him as an absolute opponent to the American conquest and even a precursor of the Mexican independence ("Con estas tesis y argumentos republicanos, De la Veracruz rechaza enérgicamente los títulos de legitimidad de la guerra de conquista, y del dominio español sobre América. Estas ideas republicanas que cuestionan el proyecto imperial de Carlos v constituyen el núcleo central de una tradición humanista que se desarrollará con diferentes matices y variantes en los siglos subsecuentes y llega a adquirir una relevancia determinante en los procesos de independencia del mundo iberoamericano a principios del siglo XIX [...]. Desde esta original teoría republicana Alonso de la Veracruz realiza una bien fundamentada crítica a la guerra de conquista y a la dominación imperial de España sobre las tierras y pueblos de América. Esta crítica es aún más firme, radical y convincente que la de sus maestros salmantinos Vitoria y Soto, precisamente porque, a diferencia de ellos, fray Alonso vivió la mayor parte de su vida en Michoacán y México, siendo testigo presencial de las ofensas e injusticias que sufrían los indios a causa de la dominación española”, Velasco Gómez, "La filosofía crítica de Alonso de la Veracruz", 1041-1043). 
Vitoria also considered all these motives legitimate and the titles of just war and appropriation of the natives' dominium adequate, but he defended them in a different order in De Indis. The right of Spaniards to travel and undertake economic activities in America, slightly weakened by Vera Cruz, appeared as his first cause of just war. Other titles appeared in the following order: 2) the right to preach the Gospel; 3) the danger of apostasy of Christianised natives; 4) the right of the pope to transfer the dominium iurisdictionis of native lords to a certain Christian ruler if a significant portion of the native population had embraced the Christian faith; 5) the obligation to fight against tyrannical rulers and to eradicate anthropophagy, ritual cannibalism, and human sacrifice; 6 ) the free choice of a certain native community or free acceptance of the transfer of dominium iurisdictionis of the native lords to a more competent Christian ruler; 7) the obligation to assist allies taking part in a just war.

The Relectio de dominio infidelium seems to be a mere rephrasing of De Indis until this point, except for Vera Cruz's justification of forced conversion and his categorical refusal of the amentia of the Indians, which Vitoria had considered a hypothesis that needed to be corroborated by greater knowledge of the native populations. Nevertheless, the conclusions of this preliminary superficial reading, which most academic writings on Vera Cruz's ideas on war and conquest are, need to be substantially revised through a closer reading of both relectiones. More attention must especially be given to the small but significant markers that indicate the nuances in different arguments, contrasting facts and ideas, and implications that weaken some of Vitoria's de iure conclusions.

It is important to take into account that there was a distinction between a de iure and a de facto level of discourse in both Vitoria and Vera Cruz, that is to say that the titles or causes that could justify a war against indigenous populations were evaluated according to two criteria. Firstly, in an abstract manner whereby the proofs that support elements of the titles were mostly traditional juridical and theological authorities from the long tradition of Christian exchanges with infidels, and other reasonable arguments. Secondly, those abstract suppositions were "localised", that is to say, their a priori validity was examined in light of the concrete circumstances of the evangelisation process in Western Indies (in the case of Vitoria's relectio) and in the central and northern regions of the Viceroyalty of New Spain (in the case of Vera Cruz's De dominio infidelium).

It is not by chance that both Vitoria and Vera Cruz formulated these titles of just war in a conditional way: "si in aliqua civitate maior pars esset christianorum et illi in favorem fidei et pro bono communi vellent habere principem christianum" [if, in some political community, the greater part is Christian and they want to have a Christian prince in order to favour the faith and for 
the common good], 88 "si istis barbaris insulanis sufficienter fuerit proposita fides" [if the faith was sufficiently explained to those barbarian islanders], 89 "si aliter tolli non potest sacrilegus ritus" [if sacrilegious rites cannot be removed otherwise ], ${ }^{90}$ "si aliqui barbarorum iustum habebant bellum cum aliis ex eisdem" [if some of those barbarians have a just war with others] ${ }^{91}$ Despite a similar point of departure in the examination of the per se or de iure validity of some traditional just war titles, Vitoria and Vera Cruz arrived at very different de facto conclusions, owing to the particular contexts and circumstances (ex circunstantia) they considered.

The main difference between the relectiones is that Vitoria's reflection was limited by his lack of direct knowledge of the American context and because fact-checking of his abstract, per se valid arguments only happened occasionally (as he himself recognised), ${ }^{92}$ whereas Vera Cruz's relectio was underpinned by his long familiarity with the Purépecha and the Nahua and the luxury of systematic fact-checking. As a result of this critical exercise, Vera Cruz rejected de facto, in brief but significant sentences, the applicability of most of the titles Vitoria had validated de iure. He rejected, for example, the validity of indiscriminate accusations of tyranny (title 3 in Vera Cruz), which had been argued as a just cause of war against native rulers from the very beginning of the conquest. ${ }^{93}$ Vera Cruz considered instead that the tyrannical character of the regimes of Moctezuma and Caltzontzin (the supreme Lord of the Purépecha) simply "non constat" [it is not agreed]. Relativising even the European parameters that defined tyranny and that were fully consolidated in

88 Vitoria, De Indis, 95 .

89 Vera Cruz, De dominio infidelium (Heredia), 157.

$90 \quad$ Vitoria, De Indis, 94.

91 Vera Cruz, De dominio infidelium (Heredia), 177.

92 Not only in his questioning approach to the natives' amentia, but also while examining other titles. For example, after considering the obstruction of missionary activities as a valid motive for waging war, he underlined that this abstract cause could only be considered a justification for a concrete war if preaching had been undertaken in a completely peaceful manner from the very beginning. "Sed nos ostendimus quod per se haec licent. Ego non dubito quin opus fuerit vi et armis, ut possent hispani illic perseverare; sed timeo ne ultra res progressa sit quam ius fasque permittebant. Iste ergo potuit esse secundus titulus legitimus, quo barbari potuerunt cadere in dicionem hispanorum. Sed Semper habendum est prae oculis quod statim dictum est, ne hoc quod per se licitum est, reddatur malum ex circunstantia, ex Aristoteli (tertio Ethicorum) et Dionysio (De divinis nominibus, cap. 4)", Vitoria, De Indis, 90-91.

93 For a general perspective on the accusations of tyranny against Moctezuma in Hernán Cortés's Cartas de Relación and later Spanish chronicles, see Rubial, "Moctezuma: de tirano soberbio y cobarde a rey prudente". 
the Aristotelian-Thomist tradition of thinking, ${ }^{94}$ he considered that it related more to the way in which a certain people perceived its own political regime local customs and the very specific circumstances of the place had to be examined when determining the suitability and appropriateness of a certain way of rule - than as an objective reality.

And, this, if these aborigines were governed tyrannically by Montezuma and Caltzontzin, the war against them was just, inasmuch as the dominion they formerly had was not legitimate. But whether they really ruled tyrannically and not for the good of the commonwealth, I do not know. Perhaps what seems tyrannical to another nation was appropriate and beneficial for this savage nation, so that it was better for them to be governed by their lords with terror and an iron hand rather than with a display of affection. ${ }^{95}$

We find the same kind of refutation on a factual basis of the titles derived from, among other things, indigenous practices of human sacrifice, anthropophagy, and ritual cannibalism (title 4 in De dominio infidelium), which no longer represented a current casus belli for Vera Cruz in the 155 os. ${ }^{96}$ The assistance the Spaniards had given to their allies from Tlaxcala (title 5) was also judged an invalid title because the justice of that war had not been factually proven by Tlaxcalans, ${ }^{97}$ just as the impediments that natives would have imposed on Spaniards - hindering their rights of free travel, commerce, and mining from

94 Aristotle provided a detailed list of measures that were usually practiced in tyrannical regimes in his Politics (1313a 4 -1315a 32), 30-35. Those measures were later considered the objective criteria for calling a government tyrannical, as can be seen in Bartolus's $D e$ tyranno, 175-213; Aquinas's De regno ad regem Cypri [On Kingship to the King of Cyprus], 13-18; Giles of Rome's De regimine principum [On the Rule of Princes]; and the myriad of scholastic authors who followed - almost literally - these pioneering writings from the 14 th to the late $17^{\text {th }}$ century. Vera Cruz's approach represented a really radical innovation vis-à-vis this standardised literature on tyranny in this sense.

95 Vera Cruz, De dominio infidelium (Burrus), 415.

96 "Et quia, fide suscepta et modo politico vivendi acceptato apud istos, non manet timor de tali saevitia iterum admittenda, spoliandi non essent suis legitimis dominiis", Vera Cruz, De dominio infidelium (Heredia), 177 .

97 "Verum ex considerationis hinc inde non videtur in facto iustificari iustum dominium Hispanorum isto titulo. Primo, quia non constat de iustitia belli ex parte Taxcalensium. Secundo, quia, etiam si fuisset iustitia, non tamen usque ad privationem dominio, ut diximus. Tertio, quod neque usque ad exspoliationem thesauri sui. Et, quia hoc negotium ex facto pendet, supposito non ignoratur ius, oportet inquirere; quia, dum est dubium, melior est conditio possidentis", Vera Cruz, De dominio infidelium (Heredia), 179. 
the very beginning of their problematic relationship (title 6) - was not proven. In this last case, Vera Cruz claimed to ignore what had really happened at the very beginning of the Euro-American encounters, also holding in abeyance the validity of this de iure title. ${ }^{98}$

Having rejected many hypothetical causes with factual complexities, only the obligation to obey Christian preachers and convert to Christianity once the "true faith" had been properly and thoroughly explained (titles 1 and 2, which also underpinned title 6) could be considered sufficient to justify a war against the natives. From Vera Cruz's perspective, violence was only legitimate if it was undertaken in response to a previous iniuria [injury] or with a clear pious motivation to evangelise, convert, or prevent the apostasy of the Mexican neophytes.

All the secular arguments offered by Vitoria to justify wars in the Indies which derived from the ius gentium rights to travel and undertake economic activities and obligations towards the oppressed and allies, fell apart. Ironically, what has been seen as the most valuable contribution of Vitoria and the School of Salamanca to modernity ${ }^{99}$ did not seem as solid and important for Vera Cruz, who, as this chapter has demonstrated, deviated from Salamanca teachings on many crucial issues.

In his concluding remarks in the introduction to this volume, Thomas Duve states that, when speaking or writing about the School of Salamanca as a case of global knowledge production, we have to consider that "normative knowledge was produced under very specific practical conditions, localised, and translated into the context of each individual case". ${ }^{100}$ That is precisely how Vera Cruz revisited the debate on the just titles 15 years after De Indis, reevaluating and localising the normative criteria that Vitoria - and before him, the long scholastic tradition - had considered as legitimate casus belli in the interrelations between Christians and infidels.

98 "Sed tamen, si forte incolae huius Orbis inermes, videntes armatos milites et robustos Hispanos, timentes non venire causa peregrinationis, sed explorandi, exspoliandi et dominandi, et sibi providentes non concederent ingressum, in tali casu non facerent iniuriam Hispanis se defendendo; neque facerent iustitiam ipsi Hispani offendendo, et si vi et violentia ingrediendo aliqua mala eis inferrent, quia tunc non esset iustitia belli ex parte Hispanorum, qui nullam passi essent iniuriam ab incolis huius Orbis. Quid a principio fuerit factum ignoramos. Ob id de iure, facto praesupposito, loquimur", Vera Cruz, De dominio infidelium (Heredia), 193.

99 A recent, well-balanced analysis of the hypothetical, modern character of Vitoria's ideas about ius gentium, whose relationship with contemporary international law has been much discussed, can be found in Beneyto, Corti Varela, At the Origins of Modernity.

See Duve, "The School of Salamanca. A case of global knowledge production". 


\section{Bibliography}

\section{Printed Sources}

Acosta, De procuranda indorum salute, vol. I, 2 vols., Madrid 1984.

Aquinas, Thomas, Summa theologiae, $I^{a}-I^{a e}$ q. 71-114 cum commentariis Caietani, Roma 1982.

Aquinas, Thomas, Summa theologiae $I^{a}-I I^{a e}$ q. 1-56 cum commentariis Caietani, Roma 1895 .

Aquinas, Thomas, De regno ad regem Cypri. On Kingship to the King of Cyprus, ed. Phelan, Gerald and Ignatius Eschmann, Toronto 1949.

Aristotle, Politics, Books V and VI, ed. Keyt, David, Oxford 1999.

Bartolus, De tyranno, ed. Quaglioni, Diego, Firenze 1983.

Cartagena, Alonso de, Los libros de Tulio: De senetute, De los ofiçios, ed. Morrás, María, Alcalá de Henares 1996.

Dullaert, Martínez Silíceo, Questiones super duos libros Peri hermeneias Aristotelis una cum textu eiusdemque clarissima expositione doctissimi magistri Johannis Dullaert de Gandano adiecta Sylicei eiusdem Dullaert discipuli cura et vigilantia, Salamanca 1517: [Juan de Porras].

Fernández de Madrigal, Alonso ('El Tostado'), Defensorium trium conclusionum, Köln 1613: Iohannes Gymnicus and Antonius Hieratus.

Fernández de Madrigal, Alonso ('El Tostado'), Commentaria in Primam Partem I. Regum, Venezia 1615: Barezzo Barezzi.

Fernández de Madrigal, Alonso ('El Tostado'), Del Tostado sobre el amor, ed. Cátedra, Pedro, Barcelona 1986.

Fernández de Madrigal, Alonso ('El Tostado'), De optima politia. El gobierno ideal, ed. Belloso, Nuria, Pamplona 2003.

Martínez Silíceo, Juan, Siliceus in eius primam Alfonseam sectionem in qua primaria dyalectices elementa comperiuntur argutissime disputata, Salamanca 1517: [Juan de Porras?].

Martínez Silíceo, Juan, Logica brevis Magistri Silicei cunctis, theologis, legumperitis, medicis, philosophis, rethoribus, grammaticus et omni literatorum sorti acommodata, Salamanca 1521: [Juan de Porras?].

Osma, Pedro de, Comentario a la "Ética" de Aristóteles, ed. Labajos Alonso, José, Salamanca 1996.

Osma, Pedro de and Fernando de Roa, Comentario a la "Política" de Aristóteles, ed. Labajos Alonso, José, Salamanca 2006.

Osma, Pedro de, Escritos académicos de Pedro de Osma, eds. Labajos Alonso, José and Pablo García Castillo, Salamanca 2010.

Roa, Fernando de, Repeticiones filosóficas del maestro Fernando de Roa, eds. Labajos Alonso, José and Pablo García Castillo, Salamanca 2007. 
Rome, Giles of, "De regimine principum. On the Rule of Princes (selection)", in McGrade, Arthur Stephen, John Kilcullen and Matthew Kempshall (eds.), The Cambridge Translations of Medieval Philosophical Texts, Volume Two. Ethics and Political Philosophy, Cambridge 2011, 200-215.

Rome, Giles of, De regimine principum. Il Livro del governamento dei re e dei principi, Vol. I, ed. Papi, Fiammetta, Pisa 2016.

Vera Cruz, Alonso de la, Recognitio summularum, México 1554: Juan Pablo Bricense.

Vera Cruz, Alonso de la, Dialectica resolutio, México 1554: Juan Pablo Bricense.

Vera Cruz, Alonso de la, Physica speculatio, México 1557: Juan Pablo Bricense.

Vera Cruz, Alonso de la, Speculum coniugiorum, Salamanca 1562: Andrea de Portonaris. Vera Cruz, Alonso de la, "De dominio infidelium et iusto bello", in Burrus, Ernest (ed.), The Writings of Alonso de la Vera Cruz, vol. II, Defense of the Indians: their Rights, 1, 5 vols., Roma - St. Louis 1968.

Vera Cruz, Alonso de la, "De decimis", in Burrus, Ernest (ed.), The Writings of Alonso de la Vera Cruz, vol. IV, Defense of the Indians: their Privileges, 5 vols., Roma - St. Louis 1976.

Vera Cruz, Alonso de la, De dominio infidelium et iusto bello. Sobre el dominio de los indios y guerra justa, ed. Heredia Correa, Roberto, México 2007.

Vera Cruz, Alonso de la, Relectio de decimis 1555-57. Tratado acerca de los diezmos, ed. Barp Fontana, Luciano, México 2015.

Vitoria, Francisco de, Comentarios a la Secunda Secundae de Santo Tomás, Vol. 3, "De justitia" (qq.57-66), 6 vols., ed. Beltrán de Heredia, Vicente, Salamanca 1934.

Vitoria, Francisco de, Relectio de Indis, ed. Pereña, Luciano and José María Pérez Prendes, Madrid 1967.

\section{Literature}

Amrán, Rica, "De Pedro Sarmiento a Martínez Silíceo: la génesis de los estatutos de limpieza de sangre", in Amrán, Rica (ed.), Autour de l'Inquisition. Études sur le Saint Office, Paris 2002, 33-56.

Aspe Armella, Virginia, "Del viejo al nuevo mundo: el tránsito de la noción de dominio y derecho natural de Francisco de Vitoria a Alonso de la Veracruz", in Revista Española de Filosofía Medieval 17 (2010), 143-155.

Aspe Armella, Virginia, "El aristotelismo de la primera etapa de la Universidad de Salamanca", in Aspe Armella, Virginia, María Idoya Zorroza (eds.), Francisco de Vitoria en la Escuela de Salamanca y su proyección en Nueva España, Pamplona 2014, 47-6o.

Aspe Armella, Virginia, "Análisis del placer y la sexualidad matrimonial en Alonso de la Veracruz", in Euphyía 10:19 (2016), 23-46.

Aspe Armella, Virginia, "Integración cultural y ley natural en el Speculum coniugiorum de Alonso de la Veracruz", in Estudios 32 (2016), 377-402. 
Aspe Armella, Virginia, Aristóteles y Nueva España, San Luis Potosí 2018.

Aspe Armella, Virginia and Maria Idoya Zorroza (eds.), Francisco de Vitoria en la Escuela de Salamanca y su proyección en Nueva España, Pamplona 2014.

Belda Plans, Juan, La Escuela de Salamanca y la renovación de la teología en el siglo XVI, Madrid 2000.

Belda Plans, Juan, Estudio crítico. Francisco de Vitoria, Madrid 2014.

Beneyto, José María, Justo Corti Varela (eds.), At the Origins of Modernity. Francisco de Vitoria and the Discovery of International Law, Cham 2017.

Belloso Martín, Nuria, Política y humanismo en el siglo XV: el maestro Alfonso de Madrigal, 'el Tostado', Valladolid 1989.

Beltrán de Heredia, Vicente, "El profesorado salmantino durante la primera mitad del s. XV”, in Vicente Beltrán de Heredia, Bulario de la Universidad de Salamanca (12191549), Tomo I, Salamanca 1966, 155-168.

Beuchot Puente, Mauricio and Walter Redmond, Pensamiento y realidad en fray Alonso de la Vera Cruz, México 1987.

Beuchot Puente, Mauricio, Historia de la filosofía en el México colonial, México 1996.

Campos Benítez, Juan Manuel, “Tomismo y nominalismo en la lógica novohispana”, in Revista Española de Filosofía Medieval 12 (2005), 135-142.

Cañas Gálvez, Francisco de Paula, Burocracia y cancillería en la corte de Juan II de Castilla (1406-1454). Estudio institucional y prosopográfico, Salamanca 2012.

Carabias Torres, Ana María, Salamanca y la medida del tiempo, Salamanca 2012.

Carrillo Cazares, Alberto, El debate sobre la guerra chichimeca, 1531-1585: derecho y política en la Nueva España, Vol. I, 2 vols., Zamora (México) 2000.

Carrillo Cazares, Alberto, Vasco de Quiroga, la pasión por el derecho: el pleito con la Orden de San Agustín 1558-1562, Zamora (México) 2003.

Castillo Vegas, Jesús Luis, Política y clases medias: el siglo XVy el maestro salmantino Fernando de Roa, Valladolid 1987.

Castillo Vegas, Jesús Luis, "Aristotelismo político en la Universidad de Salamanca del siglo XV: Alfonso de Madrigal y Fernando de Roa”, in La Corónica 33:1 (2004), 39-52.

Cerezo de Diego, Prometeo, Alonso de Veracruz (1507-1584) y el derecho de gentes, Madrid 1982.

Cervera Jiménez, José Antonio, "The School of Salamanca at the end of the known world in the 16th century: Martín de Rada, Domingo de Salazar and Juan Cobo in the Philippines, 1565-1594", in Salamanca Working Papers Series 2019:2.

Cruz Cruz, Juan, "Die praktische Rückführung des menschlichen Gesetzes auf das Naturgesetz:Die Epikie bei Vitoria", in Bunge, Kirstin, Anselm Spindler, Andreas Wagner (eds.), The Normativity of Law According to Francisco de Vitoria, Stuttgart 2011, 71-98.

Cuena Boy, Francisco, "La prohibición del matrimonio del funcionario con mujer de la provincia en la que sirve: del Derecho romano al Derecho indiano", in Cuena Boy, Francisco, Escritos romanísticos de tema indiano, Madrid 2016, 371-422. 
Cuena Boy, Francisco, “Teoría y práctica de la ley. Apuntes sobre tres juristas indianos", in Cuena Boy, Francisco, Escritos romanísticos de tema indiano, Madrid 2016, 321-35o.

Cuena Boy, Francisco, "El castigo de las injurias causadas a los indios. Una página característica de Diego de Avendaño", in Cuena Boy, Francisco, Escritos romanísticos de tema indiano, Madrid 2016, 537-562.

Delgado Jara, Inmaculada, "El Tostado y la exégesis bíblica”, in Flórez Miguel, Cirilo, Maximiliano Hernández Marcos and Roberto Albares Albares (eds.), La primera Escuela de Salamanca (1406-1516), Salamanca 2012, 55-74.

Delgado Jara, Inmaculada, "La hermeneútica bíblica en el siglo XV", in Pena González, Miguel Anxo and Luis Enrique Rodríguez-San Pedro Bezares (eds.), La Universidad de Salamanca y el Pontificado en la Edad Media, Salamanca 2014, 435-46o.

Duve, Thomas, "Salamanca in Amerika”, in Zeitschrift der Savigny-Stiftung für Rechtsge schichte: Germanistische Abteilung 132:1 (2015), 116-151.

Espona, Rafael de, "El cardenal Silíceo, príncipe español de la Contra-reforma”, in Anales de la Fundación Francisco Elías de Tejada 11 (2005), 41-61.

Flórez Miguel, Cirilo, "El ambiente cultural de la Salamanca del Renacimiento en torno a la figura de Juan Martínez 'Silíceo' ", in Llamazares, Fernando and Carlos Vizuete Mendoza (eds.), Arzobispos de Toledo, mecenas universitarios, Cuenca 2004, 111-144.

Flórez Miguel, Cirilo, "Presentación", in Flórez Miguel, Cirilo, Maximiliano Hernández Marcos and Roberto Albares Albares (eds.), La primera Escuela de Salamanca (14061516), Salamanca 2012, 9-11.

Flórez Miguel, Cirilo, Maximiliano Hernández Marcos and Roberto Albares Albares (eds.), La primera Escuela de Salamanca (1406-1516), Salamanca 2012.

Heredia Correa, Roberto, “Coacción para la fe. Una aproximación al tratado De dominio infidelium et iusto bello de fray Alonso de la Vera Cruz”, in Tópicos: Revista de Filosofía 34 (2008), 157-208.

Langella, Simona, "Fuentes manuscritas de la Escuela de Salamanca y su difusión internacional", in Rodríguez-San Pedro Bezares, Luis Enrique and Juan Luis Polo Rodríguez (eds.), Fuentes, archivos y bibliotecas para una historia de las Universidades hispánicas, Salamanca 2015, 269-289.

Lazcano, Rafael, Fray Alonso de Veracruz (1507-1584), misionero del saber y protector de indios, Madrid 2007.

López Lomelí, Claudia, "La polémica de la justicia en el tratado De dominio de Alonso de la Veracruz", in Ponce Hernández, Carolina (ed.), Innovación y tradición en fray Alonso de la Veracruz, México 2007, 133-154.

Marcos de Dios, Ángel, "Portugueses en la Universidad de Salamanca en la Edad Moderna", in Rodríguez San Pedro-Bezares, Luis Enrique (ed.), Historia de la Universidad de Salamanca, III. 2: Saberes y confluencias, Salamanca 2006, 1101-1128. 
Marcos de Dios, Ángel, Portugueses na Universidade de Salamanca (1550-1580), Salamanca 2009.

Méndez Alonzo, Manuel. "La teoría tomista del poder político de Alonso de la Veracruz y su crítica al humanismo renacentista”, in La Lámpara de Diógenes 12:22-23 (2011), 81-97.

Morrás, María "El debate entre Leonardo Bruni y Alonso de Cartagena: las razones de una polémica", in Quaderns. Revista de traducció 7 (2002), 33-57.

Monsalvo Antón, José María, "Impulso institucional e intelectual del Estudio, c. 1380c. 1480", in Rodríguez-San Pedro Bezares, Luis Enrique (ed.), La Universidad de Salamanca: Ochocientos años, Salamanca 2018, 51-108.

Pavón, Armando, "La Universidad de México en tiempos de fray Alonso de la Veracruz", in Velasco, Ambrosio (ed.), Fray Alonso de la Veracruz: universitario, humanista, científico y republicano, México 2009, 47-62.

Pena González, Miguel Anxo, "Proyecto salmantino de Universidad Pontificia e integración de la Teología en el siglo XV", in Rodríguez-San Pedro Bezares, Luis Enrique and Juan Luis Polo Rodríguez (eds.), Salamanca y su Universidad en el primer Renacimiento, siglo XV. Miscelánea Alfonso IX, Salamanca 2011, 121-16o.

Pena González, Miguel Anxo (ed.), De la Primera a la Segunda "Escuela de Salamanca". Fuentes documentales y líneas de investigación, Salamanca 2012.

Pena González, Miguel Anxo and Luis Enrique Rodríguez-San Pedro Bezares (eds.), La Universidad de Salamanca y el Pontificado en la Edad Media, Salamanca 2014.

Pereña, Luciano, "Francisco de Vitoria en Portugal”, in Arbor 46 (196o), 326-341.

Quantin, Jean-Louis, "Catholic Moral Theology, 1550-1800”, in Lehner, Ulrich, Richard Müller and Anthony Gregg Roeber (eds.), The Oxford Handbook of Early Modern Theology, 1600-180o, Oxford 2016, 119-134.

Quero, Fabrice, Juan Martínez Silíceo (1486?-1557) et la spiritualité de l'Espagne prétridentine, Paris 2014.

Quijano Velasco, Francisco, "Alonso de la Veracruz: Natural Law, Dominion and Political Legitimacy in Native American Governance", in Paul, Joanne (ed.), Governing Diversities: Democracy, Diversity and Human Nature, Cambridge 2012, 89-106.

Quijano Velasco, Francisco, Las repúblicas de la Monarquía. Pensamiento constitucionalista y republicano en Nueva España, 1550-1610, México 2017.

Ramírez González, Clara Inés, "Alonso de la Veracruz en la Universidad de Salamanca: entre el tomismo de Vitoria y el nominalismo de Martínez Silíceo", in Salmanticenses 54 (2007), 635-652.

Redmond, Walter, Bibliography of the Philosophy in the Iberian colonies of America, Den Haag 1972.

Redmond, Walter and Mauricio Beuchot Puente, La lógica mexicana del siglo de oro, México 1985. 
Rivera García, Antonio, "Humanismo, representación y angelología. El conciliarismo de Juan de Segovia”, in Flórez Miguel, Cirilo, Maximiliano Hernández Marcos and Roberto Albares Albares (eds.), La primera Escuela de Salamanca (1406-1516), Salamanca 2012, 95-113.

Rodríguez-San Pedro Bezares, Luis Enrique, "La Universidad de Salamanca: de los reyes a los pontífices, 1255-1450", in Pena González, Miguel Anxo and Luis Enrique Rodríguez-San Pedro Bezares (eds.), La Universidad de Salamanca y el Pontificado en la Edad Media, Salamanca 2014, 185-216.

Rovira Gaspar, María del Carmen, "Relación entre la tercera parte de la relección Sobre los indios de Vitoria y la cuestión VI del tratado De iusto bello contra indos de Alonso de la Veracruz", in Ponce Hernández, Carolina (ed.), Innovación y tradición en fray Alonso de la Veracruz, México 2007, 155-180.

Rubial, Antonio, "Moctezuma: de tirano soberbio y cobarde a rey prudente. Construcción retórica de un personaje emblemático de Nueva España", in Temas y variaciones de literatura 28 (2007), 15-26.

Sabido, Cecilia, El pensamiento ético-político de Alfonso de Madrigal: el aristotelismo en la escuela humanista de Salamanca del siglo XV, Pamplona 2016.

Tau Anzoátegui, Víctor, "La idea de derecho en la colonización española de América", in Tau Anzoátegui, Víctor, El Jurista en el Nuevo Mundo. Pensamiento. Doctrina. Mentalidad, Frankfurt 2016, 25-33.

Torre Rangel, Jesús Antonio de la, "Una expresión del pensamiento novohispano en el reino del Perú: el memorial de Las Casas y fray Domingo de Santo Tomás de 156o", in Pensamiento Novohispano 19 (2018), 49-58.

Vega Reñón, Luis, "Alonso de Veracruz y las encrucijadas de la lógica en el siglo XVI", in Cuadernos Salmantinos de Filosofía 30 (2003), 119-133.

Velasco Gómez, Ambrosio, "La filosofía crítica de Alonso de la Veracruz a 500 años de la conquista: pluralidad, justicia y libertad" in Revista Portuguesa de Filosofía 75:2 (2019), 1023-1046.

Villacañas Berlanga, José Luis, "La ratio teológica-paulina de Alfonso de Cartagena”, in Flórez Miguel, Cirilo, Maximiliano Hernández Marcos and Roberto Albares Albares (eds.), La primera Escuela de Salamanca (1406-1516), Salamanca 2012, 75-94.

Wittlin, Curt, "El oficio de traductor según Alfonso Tostado de Madrigal en su comentario al prólogo de san Jerónimo a las Crónicas de Eusebio", in Quaderns. Revista de traducció 2 (1998), 9-21.

Zavala, Silvio, Fray Alonso de la Veracruz: primer maestro de derecho agrario en la incipiente Universidad de México, 1553-1555, México 1981. 